\title{
Comparative Study of $\mathrm{M}\left[\mathrm{N}\left(\mathrm{SO}_{2} \mathrm{~F}\right)\left(\mathrm{SO}_{2} \mathrm{CF}_{3}\right)\right]-$
}

[ $N$-butyl- $N$-methylpyrroridinium] $\left[\mathrm{N}\left(\mathrm{SO}_{2} \mathrm{~F}\right)\left(\mathrm{SO}_{2} \mathrm{CF}_{3}\right)\right] \quad(\mathrm{M}$

$=\mathrm{Li}, \mathrm{Na}, \mathrm{K}, \mathrm{Rb}, \mathrm{Cs})$ Ionic Liquid Electrolytes

Takayuki Yamamoto, * Shu Nishijima, and Toshiyuki Nohira*

Institute of Advanced Energy, Kyoto University, Uji 611-0011, Japan

KEYWORDS: Alkali metal-ion battery, Ionic liquid,

(Fluorosulfonyl)(trifluoromethylsulfonyl)amide 


\section{ABSTRACT}

We systematically evaluated the physicochemical properties of a series of M[FTA]$\left[\mathrm{C}_{4} \mathrm{C}_{1}\right.$ pyrr][FTA $]$ ionic liquids (ILs) $(\mathrm{M}=$ alkali metal, $\mathrm{FTA}=$ (fluorosulfonyl)(trifluoromethylsulfonyl)amide, $\mathrm{C}_{4} \mathrm{C}_{1}$ pyrr $=N$-butyl- $N$-methylpyrrolidinium) as electrolytes for alkali metal-ion batteries. First, the viscosity $(\eta)$, ionic conductivity $(\sigma)$, and density $(\rho)$ of the M[FTA] $-\left[\mathrm{C}_{4} \mathrm{C}_{1}\right.$ pyrr][FTA] ILs (molar fraction of M[FTA]: $x(\mathrm{M}[\mathrm{FTA}])=0.20$ ) were measured. The $\sigma$ values ranged from $1-3 \mathrm{mS} \mathrm{cm}^{-1}$ at $298 \mathrm{~K}$ and increased as follows: $\mathrm{Na}<\mathrm{Li}$ $<\mathrm{K}<\mathrm{Rb}<\mathrm{Cs}$, which indicated that the Li-based IL did not obey the trend predicted by the charge densities of alkali metal cations. Second, the Li-based IL exhibited slightly lower vertical intercept values than the other FTA-based ILs in the Walden plots obtained using the results of $\eta$, $\sigma$, and $\rho$ measurements. Third, the electrochemical stability of the ILs was investigated by cyclic voltammetry, and the redox potentials of the alkali metals $\left(E\left(\mathrm{M}^{+} / \mathrm{M}\right)\right)$ were determined. The $E\left(\mathrm{M}^{+} / \mathrm{M}\right)$ values of the FTA-based ILs increased as follows: $\mathrm{Cs}<\mathrm{Rb}<\mathrm{K}<\mathrm{Li}<\mathrm{Na}$. Subsequently, we compared the obtained $E\left(\mathrm{M}^{+} / \mathrm{M}\right)$ values with those of other general electrolytes, such as propylene carbonate (PC)-based electrolytes and aqueous solutions. The trend in $E\left(\mathrm{M}^{+} / \mathrm{M}\right)$ values of the FTA-based ILs was similar to that of PC-based electrolytes and was significantly different from that of aqueous solutions. In particular, the FTA- and FSA-based ILs (FSA = bis(fluorosulfonyl)amide) presented the most negative $E\left(\mathrm{Na}^{+} / \mathrm{Na}\right)$ and $E\left(\mathrm{~K}^{+} / \mathrm{K}\right)$ values among various electrolytes, which indicated that utilization of these IL electrolytes for the development of Na- and K-ion batteries would present significant advantages. 


\section{INTRODUCTION}

The establishment of a low-carbon society is one of our final goals toward achieving a sustainable energy supply and demand cycle and solving various environmental problems. Renewable energy resources present lower greenhouse gas emissions than the conventional large power plants based on fossil fuels and nuclear power, and are feasible for small-scale electricity production in microgrids. Although renewable energy resources are promising next-generation primary energy sources, their electricity production largely depends on the weather and climate. Thus, energy storage devices are indispensable for a stable power supply. Li-ion batteries (LIBs) are potential candidates as stationary power storage devices in microgrids and also for electric vehicles because they possess high energy densities and have been widely used for portable electric devices, such as mobile phones and laptops. Although upsizing the current LIBs is needed to further expand their applications for microgrids, two main drawbacks should be overcome: the scarcity and uneven distribution of lithium and cobalt resources, which could cause steep price increases depending on the political situation, and the use of flammable and volatile organic solvent-based electrolytes. Therefore, our group has focused on Na- and K-ion batteries (NIBs and KIBs, respectively) with ionic liquid (IL) electrolytes as next-generation energy storage devices. ${ }^{1-}$

${ }^{3}$ Sodium and potassium resources are abundant in the Earth's crust, which facilitates the construction of many batteries using inexpensive raw materials. ${ }^{4-7}$

ILs consist only of cations and anions and present unique properties, such as negligible volatility, nonflammability, and high electrochemical and thermal stability. Thus, ILs have been used as safe and high-performance electrolytes for various electrochemical devices, including batteries, capacitors, and fuel cells. ${ }^{1,8,9}$ We have recently reported FSA-based IL electrolytes (FSA $=$ bis(fluorosulfonyl)amide) for KIBs ${ }^{2}$ and compared the physicochemical and electrochemical 
properties of the ILs with alkali metal cations $\left(\mathrm{Li}^{+}, \mathrm{Na}^{+}\right.$, and $\left.\mathrm{K}^{+}\right)$as charge carriers. The redox potential of potassium is more negative than that of lithium in these ILs. On the other hand, it is well known that the redox potential of lithium is the most negative in aqueous solutions. ${ }^{10}$ Thus, to analyze the operating voltages of alkali metal-ion batteries, comprehensive studies should be performed to determine the properties of the electrolytes, including the redox potentials of the alkali metals in IL electrolytes and other typical liquid electrolytes.

In this study, we focused on IL electrolytes that consists of $\mathrm{FTA}^{-}$anions $(\mathrm{FTA}=$ (fluorosulfonyl)(trifluoromethysulfonyl)amide). The FTA-based ILs exhibit higher thermal stability and lower melting points than the FSA-based ILs, ${ }^{11-13}$ and thus confer wider operation temperature windows to electrochemical devices. Despite these advantages, few studies have been conducted on FTA-based ILs as battery electrolytes. ${ }^{14-16}$ Thus, we investigated the physicochemical and electrochemical properties of $\left[\mathrm{C}_{4} \mathrm{C}_{1}\right.$ pyrr] $]$ FTA $] \quad\left(\mathrm{C}_{4} \mathrm{C}_{1}\right.$ pyrr $=$ $N$-butyl- $N$-methylpyrrolidinium) and M[FTA]-[C $\mathrm{C}_{4} \mathrm{C}_{1}$ pyrr][FTA] (M = Li, Na, K, Rb, Cs) ILs, and analyzed the effects of the alkali metal cations on their properties. Lastly, we compared the obtained redox potentials of the alkali metals with those of other common electrolytes, such as PC-based electrolytes and aqueous solutions.

\section{EXPERIMENTAL}

All reagents were handled under a dry $\mathrm{Ar}$ atmosphere. $\left[\mathrm{C}_{4} \mathrm{C}_{1}\right.$ pyrr $][\mathrm{FTA}] \mathrm{IL}$ and $\mathrm{M}[\mathrm{FTA}](\mathrm{M}=$ $\mathrm{Li}, \mathrm{Na}, \mathrm{K}, \mathrm{Rb}$, and Cs) salts were purchased from Provisco CS Ltd., and were dried at $333 \mathrm{~K}$ for 24 $\mathrm{h}$ prior to use. The water contents of the reagents were tested to be less than $100 \mathrm{ppm}$ using the Karl Fisher titration method. M[FTA]-[C $\mathrm{C}_{4} \mathrm{C}_{1}$ pyrr][FTA] binary ILs (molar fraction of M[FTA]: $x(\mathrm{M}[\mathrm{FTA}])=0.20$ ) were prepared by mixing the two salts in a dry Ar-filled glove box. The thermal behaviors of the ILs were analyzed using a differential scanning calorimetry (DSC) 
instrument (DSC8230, Rigaku Co.). The viscosities $(\eta)$ of the ILs were measured using an electromagnetically spinning viscometer (EMS-1000, Kyoto Electronics Manufacturing Co., Ltd.) in the temperature range of $273-388 \mathrm{~K}$ at $5 \mathrm{~K}$ intervals. The ionic conductivities $(\sigma)$ of the ILs were obtained via AC impedance spectroscopy as follows. First, the cell constant of a T-shaped polytetrafluoroethylene cell $\left(K_{\text {cell }}\right)$ was determined using a standard $0.1 \mathrm{~mol} \mathrm{dm}^{-3} \mathrm{KCl}$ aqueous solution. Subsequently, the bulk impedance of the FTA-based ILs $\left(R_{\mathrm{IL}}\right)$ was measured, and lastly, the ionic conductivities $\left(\sigma_{\mathrm{IL}}\right)$ of the ILs were calculated by dividing $K_{\text {cell }}$ by $R_{\mathrm{IL}}\left(\sigma_{\mathrm{IL}}=K_{\mathrm{cell}} / R_{\mathrm{IL}}\right)$. The densities $(\rho)$ of the ILs were determined using a vibration-type density meter (DA-650, Kyoto Electronics Manufacturing Co., Ltd.) in the temperature range of 273-368 K at $5 \mathrm{~K}$ intervals.

Cyclic voltammetry measurements were conducted at $298 \mathrm{~K}$ using an electrochemical measurement system (HZ-7000, Hokuto Denko Corp.). A three-electrode cell was used to determine the electrochemical windows (EWs) of the FTA-based ILs. A Cu or glassy carbon disk was used as the working electrode for the negative and positive potential regions, respectively; a Pt mesh was used as the counter electrode; and the reference electrode was a Ag wire immersed in $\left[\mathrm{C}_{3} \mathrm{C}_{1}\right.$ pyrr] $[\mathrm{FSA}] \mathrm{IL}\left(\mathrm{C}_{3} \mathrm{C}_{1}\right.$ pyrr $=N$-methyl- $N$-propylpyrrolidinium $)$ which contained $50 \mathrm{mmol}$ $\mathrm{dm}^{-3}$ silver trifluoromethanesulfonate. The scan rate was set at $5 \mathrm{mV} \mathrm{s}^{-1}$.

\section{RESULTS AND DISCUSSION}

\subsection{Physicochemical properties}

Prior to the DSC measurements of the $\left[\mathrm{C}_{4} \mathrm{C}_{1}\right.$ pyrr][FTA] and $\mathrm{M}[\mathrm{FTA}]-\left[\mathrm{C}_{4} \mathrm{C}_{1}\right.$ pyrr][FTA] $(x(\mathrm{M}[\mathrm{FTA}])=0.20 ; \mathrm{M}=\mathrm{Li}, \mathrm{Na}, \mathrm{K}, \mathrm{Rb}, \mathrm{Cs})$ ILs, we confirmed the thermal behaviors of the $\mathrm{M}[\mathrm{FTA}]$ single salts. Our results are in good agreement with those previously reported in the literature (Fig. S1). ${ }^{12}$ Fig. 1 illustrates the DSC curves of the FTA-based ILs at a scan rate of $2 \mathrm{~K}$ $\min ^{-1} \cdot\left[\mathrm{C}_{4} \mathrm{C}_{1}\right.$ pyrr] $[\mathrm{FTA}]$ exhibits only glass transition behavior at approximately $170 \mathrm{~K}$, indicating 
that supercooling occurs under these measurement conditions. Conversely, the $\left[\mathrm{C}_{n} \mathrm{C}_{1}\right.$ pyrr] $[\mathrm{FSA}]$ ILs $(n=3,4)$ easily crystallize at scan rates lower than $5 \mathrm{~K} \mathrm{~min}^{-1}{ }^{2,17}$ Thus, supercooling is likely to occur in the FTA-based ILs owing to the asymmetric structure of the FTA ${ }^{-}$anion. All M[FTA]$\left[\mathrm{C}_{4} \mathrm{C}_{1}\right.$ pyrr][FTA] ILs, except for the Li-based IL, present similar trends, and their glass transition behavior is observed in the temperature range of $180-190 \mathrm{~K}$. Li[FTA $]-\left[\mathrm{C}_{4} \mathrm{C}_{1}\right.$ pyrr][FTA] exhibits crystallization and melting behaviors between 230 and $260 \mathrm{~K}$, and its end temperature of melting is determined to be $262 \mathrm{~K}$. This exceptional solidification behavior can be attributed to the presence of $\mathrm{Li}^{+}$cations, which interacts strongly with the $\mathrm{FTA}^{-}$anions. In addition, according to the previous report on $\quad \mathrm{Li}[\mathrm{FTA}]-\left[\mathrm{C}_{2 \mathrm{O} 1} \mathrm{C}_{1}\right.$ pyrr $][\mathrm{FTA}] \quad\left(\mathrm{C}_{2 \mathrm{O}} \mathrm{C}_{1}\right.$ pyrr $=$ $N$-methoxyethyl- $N$-methylpyrroridinium) system, ${ }^{15}$ the IL exhibited only glass transition behavior at a scan rate of $5 \mathrm{~K} \mathrm{~min}^{-1}$. Thus, the crystallization behavior is likely to be affected by scan rates. Overall, the DSC results suggest that the use of FTA-based IL electrolytes confers wide operation temperature windows to electrochemical devices.

Fig. 2 presents the Arrhenius plots of viscosities $(\eta)$ for the FTA-based ILs, and the $\eta$ values are summarized in Table S1. The $\eta$ values of the Na-based IL and pure $\left[\mathrm{C}_{4} \mathrm{C}_{1}\right.$ pyrr][FTA] at $298 \mathrm{~K}$ are the highest (149 $\mathrm{mPa} \mathrm{s})$ and lowest $(51.0 \mathrm{mPa} \mathrm{s})$, respectively, of all FTA-based ILs. The $\eta$ plots of the IL cannot be fitted with straight lines, which is typical for viscous and glass-like compounds. ${ }^{18}$ Therefore, the $\eta$ plots are usually fitted with the Vogel-Tammann-Fulcher (VTF) equation, as follows:

$$
\eta(T)=A_{\eta} T^{1 / 2} \exp \left(\frac{B_{\eta}}{T-T_{0 \eta}}\right)
$$

where $T$ is the absolute temperature, $T_{0 \eta}$ is the ideal glass transition temperature, and $A_{\eta}$ and $B_{\eta}$ are constants related to the frequency factor and activation energy, respectively. The VTF parameters of all FTA-based ILs are provided in Table S6. 
Fig. 3 illustrates the Arrhenius plots of the ionic conductivities $(\sigma)$ of the FTA-based ILs. The pure $\left[\mathrm{C}_{4} \mathrm{C}_{1}\right.$ pyrr][FTA] and Na-based IL exhibit the highest $\left(4.4 \mathrm{mS} \mathrm{cm}^{-1}\right)$ and lowest $(1.7 \mathrm{mS}$ $\mathrm{cm}^{-1}$ ) $\sigma$ values at $298 \mathrm{~K}$, respectively (see Table $\mathrm{S} 2$ ). The $\sigma$ value of $\left[\mathrm{C}_{4} \mathrm{C}_{1}\right.$ pyrr] [FTA] has been previously reported to be $3.5 \mathrm{mS} \mathrm{cm}{ }^{-1}$ at $293 \mathrm{~K},{ }^{19}$ which is consistent with our result $\left(3.7 \mathrm{mS} \mathrm{cm}^{-1}\right.$ at $293 \mathrm{~K}$ ). Moreover, the ionic conductivity of the $\left[\mathrm{C}_{4} \mathrm{C}_{1}\right.$ pyrr][FTA] IL is lower and higher than those of the $\left[\mathrm{C}_{4} \mathrm{C}_{1}\right.$ pyrr $][\mathrm{FSA}]\left(5.25 \mathrm{mS} \mathrm{cm}{ }^{-1}\right.$ at $\left.293 \mathrm{~K}^{20}\right)$ and $\left[\mathrm{C}_{4} \mathrm{C}_{1}\right.$ pyrr $][\mathrm{TFSA}]\left(2.21 \mathrm{mS} \mathrm{cm}^{-1}\right.$ at $293 \mathrm{~K}^{21}$; TFSA = bis(trifluoromethylsulfonyl)amide)) counterpart ILs, respectively. The nonlinear dependence of $\sigma$ on $T$ observed in Fig. 3 can be explained using the following VTF fitting equation:

$$
\sigma(T)=\frac{A_{\sigma}}{T^{1 / 2}} \exp \left(-\frac{B_{\sigma}}{T-T_{0 \sigma}}\right)
$$

where $T_{0 \sigma}$ is the ideal glass transition temperature and $A_{\sigma}$ and $B_{\sigma}$ are constants related to the frequency factor and activation energy, respectively. The fitting results are summarized in Table S6.

Fig. 4 depicts the density plots of pure $\left[\mathrm{C}_{4} \mathrm{C}_{1}\right.$ pyrr $][\mathrm{FTA}]$ and the $\mathrm{M}[\mathrm{FTA}]-\left[\mathrm{C}_{4} \mathrm{C}_{1}\right.$ pyrr $][\mathrm{FTA}]$ $(x(\mathrm{M}[\mathrm{FTA}])=0.20 ; \mathrm{M}=\mathrm{Li}, \mathrm{Na}, \mathrm{K}, \mathrm{Rb}, \mathrm{Cs})$ ILs. Pure $\left[\mathrm{C}_{4} \mathrm{C}_{1}\right.$ pyrr] $[\mathrm{FTA}]$ possess the lowest $\rho$, and the $\rho$ values of the FTA-based ILs increase with the size of the alkali metal cations in the ILs. The $\rho$ plots of all ILs can be fitted linearly. Table 3 summarizes the obtained $\rho$ values and their fitting parameters. The $\rho$ of pure $\left[\mathrm{C}_{4} \mathrm{C}_{1}\right.$ pyrr] [FTA] is $1.357 \mathrm{~g} \mathrm{~cm}^{-3}$ at $298 \mathrm{~K}$, which is higher and lower than those of $\left[\mathrm{C}_{4} \mathrm{C}_{1}\right.$ pyrr][FSA $]\left(1.307 \mathrm{~g} \mathrm{~cm}^{-3}\right.$ at $\left.298 \mathrm{~K}^{20}\right)$ and $\left[\mathrm{C}_{4} \mathrm{C}_{1}\right.$ pyrr][TFSA] $\left(1.395 \mathrm{~g} \mathrm{~cm}^{-3}\right.$ at $298 \mathrm{~K}^{21}$ ), respectively. Such dependence of $\rho$ on the anion species are consistent with the data previously reported for ammonium-based IL systems. ${ }^{13}$ Table S4 summarizes the molar concentrations of alkali metal cations $\left(C\left(\mathrm{M}^{+}\right)\right)$of the M[FTA $]-\left[\mathrm{C}_{4} \mathrm{C}_{1}\right.$ pyrr] $[\mathrm{FTA}]$ ILs $((x(\mathrm{M}[\mathrm{FTA}])$ $=0.20)$, which are calculated using their $\rho$ values. The $C\left(\mathrm{M}^{+}\right)$values of all FTA-based ILs range 
between 0.80 and $0.82 \mathrm{~mol} \mathrm{dm}^{-3}$.

Table 1 summarizes the melting temperature and other physicochemical properties at $298 \mathrm{~K}$ of the FTA-based ILs. As mentioned above, the melting behavior was observed for only Li-based system. The $\eta, \sigma, \rho$, and $C\left(\mathrm{M}^{+}\right)$values of the FTA-based ILs increase as follows:

$\eta / \mathrm{mPas} \quad$ pure IL $(51.0)<\mathrm{Cs}(97.4)<\mathrm{Li}(117) \approx \mathrm{Rb}(119)<\mathrm{K}(128)<\mathrm{Na}(149)$

$\sigma / \mathrm{mS} \mathrm{cm}^{-1} \quad \mathrm{Na}(1.7)<\mathrm{Li}(2.0)<\mathrm{K}(2.2)<\mathrm{Rb}(2.3)<\mathrm{Cs}(2.6)<$ pure IL (4.4)

$\rho / \mathrm{g} \mathrm{cm}^{-3} \quad$ pure IL $(1.357)<\mathrm{Li}(1.416)<\mathrm{Na}(1.427)<\mathrm{K}(1.431)<\mathrm{Rb}(1.464)<\mathrm{Cs}$

$C\left(\mathrm{M}^{+}\right) / \mathrm{mol} \mathrm{dm}^{-3} \mathrm{Cs}(0.806)<\mathrm{Rb}(0.811)<\mathrm{K}(0.814)<\mathrm{Na}(0.819)<\mathrm{Li}(0.820)$

Because ionic liquids consist only of cations and anions, the ion-ion interactions are considered to be the main factor that determines their ionic mobility. Typically, weaker interactions between the alkali metal cations and anions result in higher ionic mobility. Thus, the M[FTA]$\left[\mathrm{C}_{4} \mathrm{C}_{1}\right.$ pyrr] $[\mathrm{FTA}]$ ILs with larger-sized alkali metal cations having lower charge densities are anticipated to present weaker ion-ion interactions and higher $\sigma$ values. Although the $\mathrm{Na}-, \mathrm{K}-, \mathrm{Rb}-$, and Cs-based systems obey this rule, the $\eta$ and $\sigma$ values of the Li-based IL are lower and higher, respectively, than expected. A similar trend was reported for the $\mathrm{M}[\mathrm{FSA}]-\left[\mathrm{C}_{3} \mathrm{C}_{1}\right.$ pyrr $][\mathrm{FSA}]$ ILs $(\mathrm{M}=\mathrm{Li}, \mathrm{Na}, \mathrm{K}) .{ }^{2}$ In addition, $\mathrm{Li}[\mathrm{TFSA}]$ has been previously reported to present the highest $\eta$ and lowest $\sigma$ of all the single M[TFSA] $(\mathrm{M}=\mathrm{Li}, \mathrm{Na}, \mathrm{K}, \mathrm{Rb}, \mathrm{Cs})$ molten salts in the temperature range of $543-573 \mathrm{~K} .{ }^{22}$ Furthermore, Li[FSA]-PC and Li[FSA]-EC-DEC presented the lowest $\sigma$ values at $298 \mathrm{~K}$ of all M[FSA]-PC and M[FSA]-EC-DEC $(\mathrm{M}=\mathrm{Li}, \mathrm{Na}, \mathrm{K} ; \mathrm{EC}=$ ethylene carbonate; DEC = diethyl carbonate) organic solvent-based electrolytes. ${ }^{7,23}$ Therefore, the effects of the alkali metal cations on the electrolyte properties have not been entirely elucidated.

Fig. 5 shows the relationships between the molar ionic conductivities $(\lambda)$ and inverse of the $\eta$ 
values of the FTA-based ILs, which are termed the Walden plots. The $\lambda$ values are provided in Table S5. All plots lie in the slightly lower right region of the ideal $\mathrm{KCl}$ line, and therefore the ILs are classified as "good" ILs. ${ }^{24}$ Moreover, these plots are fitted with straight lines in accordance with the fractional Walden rule, as follows: ${ }^{24-26}$

$$
\lambda \eta^{\alpha}=\text { constant }
$$

where $\alpha$ is a constant $(0<\alpha<1)$ that corresponds to the slope of the Walden plot. The $\alpha$ values of all ILs range between 0.91 and 0.94 , which are similar to the values previously reported for other IL electrolytes (Table 2). ${ }^{2,20,27-29}$ When $T_{0}=T_{0 \eta}=T_{0 \sigma}$, Eq. (3) can be expressed as:

$$
\lambda \eta^{\alpha}=\sigma(T) \frac{M}{\rho(T)} \eta(T)^{\alpha}=\frac{M A_{\eta}{ }^{\alpha} A_{\sigma} T^{\frac{\alpha-1}{2}}}{\rho(T)} \exp \left(\frac{\alpha B_{\eta}-B_{\sigma}}{T-T_{0}}\right),
$$

where $M$ is the formula weight of the ionic liquid. Lastly, the following equation is derived from the assumption that $T^{(\alpha-1) / 2}$ and $\rho(T)$ are constant in the measurement temperature range:

$$
\alpha=\frac{B_{\sigma}}{B_{\eta}}
$$

The $\alpha$ values of all the ILs in this study are calculated using Eq. (5), and the results are presented in Table S6. The calculated values are very close to the slopes of the Walden plots, which indicates the validity of the VTF fittings for $\eta$ and $\sigma$.

The vertical intercept of the Walden plot, $C^{\prime}=\log \left(\lambda \eta^{\alpha}\right)$, is an important factor that determines the ion transport properties of various electrolytes. Here, $C^{\prime}=\log (\lambda)$ at $\eta=100 \mathrm{mPa}$ s. Table 2 summarizes the $\alpha$ and $C^{\prime}$ constants of selected ILs and molten salts. First, the $C^{\prime}$ value of the $\mathrm{Li}[\mathrm{FTA}]-\left[\mathrm{C}_{4} \mathrm{C}_{1}\right.$ pyrr][FTA] IL is slightly more negative than those of the other M[FTA]$\left[\mathrm{C}_{4} \mathrm{C}_{1}\right.$ pyrr][FTA] ILs in this study. However, no other apparent trends in $C^{\prime}$ are observed for the effects of the alkali metal cations on the Walden plots. Second, we compared the FTA-based ILs in this study with two common amide-based ILs with $\mathrm{C}_{4} \mathrm{C}_{1}$ pyrr ${ }^{+}$cations: $\left[\mathrm{C}_{4} \mathrm{C}_{1}\right.$ pyrr] $[\mathrm{FSA}]$ and 
$\left[\mathrm{C}_{4} \mathrm{C}_{1}\right.$ pyrr][TFSA]. Because the $\alpha$ and $C^{\prime}$ values of $\left[\mathrm{C}_{4} \mathrm{C}_{1}\right.$ pyrr] $[\mathrm{FSA}]$ were reported to be 0.913 and $-0.067,{ }^{20}$ and those of $\left[\mathrm{C}_{4} \mathrm{C}_{1}\right.$ pyrr $][\mathrm{TFSA}]$ were 0.924 and $-0.180,{ }^{21}$ respectively, the dependence of $\alpha$ and $C^{\prime}$ on the anion species appears to be negligible.

According to a report on single M[TFSA] molten salts, ${ }^{22}$ the $\alpha$ values of the Li, Na, and $\mathrm{K}$ salts were approximately 0.85 , which were smaller than those of other room-temperature ILs. Moreover, using the Walden plot reported by Kubota et al., ${ }^{22}$ the $C^{\prime}$ value of Li[TFSA] was -0.381 . This is distinctively more negative than those of the other M[TFSA] melts and indicates the poorer dissociation extent of the Li[TFSA] melt. Tsuzuki et al. previously reported the stable geometries of alkali metal cations and the three amide anions $\left(\mathrm{FSA}^{-}, \mathrm{FTA}^{-}\right.$, and $\left.\mathrm{TFSA}^{-}\right)$via ab initio molecular orbital calculations. ${ }^{30}$ The calculated stabilization energies of the most stable geometries were more negative for the Li salts and less negative for the Cs salts, which was consistent with the trend in the charge densities of the alkali metal cations. The results reported by Tsuzuki et al. were in good agreement with those derived from the Walden plots of the single M[TFSA $]$ melts. ${ }^{22}$ Thus, a similar trend is naturally anticipated for the single M[FTA] melts. In this study, however, no obvious trends are found in the M[FTA]-[C ${ }_{4} \mathrm{C}_{1}$ pyrr $][\mathrm{FTA}] \mathrm{ILs}$, as shown in Table 2. Because the molar fractions of $\mathrm{M}[\mathrm{FTA}]$ and $\left[\mathrm{C}_{4} \mathrm{C}_{1}\right.$ pyrr $][\mathrm{FTA}]$ are 0.20 and 0.80 , respectively, the poorer dissociative nature of $\mathrm{Li}[\mathrm{FTA}]$ appears to be diluted by the dominant organic cations, which results in the $C^{\prime}$ value of Li[FTA] being slightly more negative than those of the other M[FTA] ILs.

\subsection{Electrochemical properties}

Fig. 6 presents the cyclic voltammograms of pure $\left[\mathrm{C}_{4} \mathrm{C}_{1}\right.$ pyrr][FTA] and M[FTA]$\left[\mathrm{C}_{4} \mathrm{C}_{1}\right.$ pyrr $][\mathrm{FTA}](x(\mathrm{M}[\mathrm{FTA}])=0.20 ; \mathrm{M}=\mathrm{Li}, \mathrm{Na}, \mathrm{K}, \mathrm{Rb}, \mathrm{Cs})$ ILs. The cathodic currents of pure 
$\left[\mathrm{C}_{4} \mathrm{C}_{1}\right.$ pyrr $][\mathrm{FTA}]$ are observed in the negative potential region below $-3.0 \mathrm{~V}\left(\mathrm{vs} . \mathrm{Ag}^{+} / \mathrm{Ag}\right)$ and sharply increases at approximately $-3.5 \mathrm{~V}$ (vs. $\mathrm{Ag}^{+} / \mathrm{Ag}$ ). This trend is consistent with that previously reported in the literature and is attributed to the reductive decomposition of the $\mathrm{C}_{4} \mathrm{C}_{1}$ pyrr ${ }^{+}$cation. ${ }^{19}$ In the positive potential region, the anodic currents are observed above $2.0 \mathrm{~V}$ (vs. $\mathrm{Ag}^{+} / \mathrm{Ag}$ ), and are ascribed to the oxidative decomposition of the $\mathrm{FTA}^{-}$anion. ${ }^{14,19}$ When the limit potential is defined as the point at which the absolute value of the current density reaches 0.1 $\mathrm{mA} \mathrm{cm}{ }^{-2}$, the cathodic $\left(E_{\mathrm{CL}}\right)$ and anodic $\left(E_{\mathrm{AL}}\right)$ limit potentials are -2.98 and $1.96 \mathrm{~V}\left(\mathrm{vs} . \mathrm{Ag}^{+} / \mathrm{Ag}\right)$, respectively, and thus the electrochemical window $(\mathrm{EW})$ is $4.94 \mathrm{~V}$. In the previous study on pure $\left[\mathrm{C}_{4} \mathrm{C}_{1}\right.$ pyrr][FTA], EW was determined to be $5.71 \mathrm{~V}$ at $293 \mathrm{~K}$ by linear sweep voltammetry. ${ }^{19}$ Although the current density threshold was the same as our criterion $\left(0.1 \mathrm{~mA} \mathrm{~cm}^{-2}\right)$, the scan rate was as low as $1 \mathrm{mV} \mathrm{s}^{-1}$, which was one-fifth of that used in the present study. In general, larger EW values can be obtained at lower scan rates, which in turn might give unrealistic information for practical application. Thus, we adopted a relatively strict criterion of $5 \mathrm{mV} \mathrm{s}^{-1}$ in the present study.

Similar anodic behaviors are observed for the M[FTA]-[C $\mathrm{C}_{4}$ pyrr][FTA] ILs. Table 3 summarizes the electrochemical properties of all the FTA-based ILs in this study. All alkali metal-ion systems presents similar $E_{\mathrm{AL}}$ values (1.91-1.97 V (vs. $\left.\mathrm{Ag}^{+} / \mathrm{Ag}\right)$ ), which indicates that the decomposition of the $\mathrm{FTA}^{-}$anion determines their anodic stability. Conversely, $E_{\mathrm{CL}}$ depends on the alkali metal ion species. For example, for the Li-ion system, a steep increase in the reduction current was observed from approximately $-3.5 \mathrm{~V}$ (vs. $\left.\mathrm{Ag}^{+} / \mathrm{Ag}\right)$ during the potential sweep in the negative direction, which corresponds to the electrodeposition of Li metal. During the potential sweep in the positive direction, the current linearly increases from negative to positive, and the intercept with the potential axis, i.e. the zero-current potential, is $-3.48 \mathrm{~V}$ (vs. $\mathrm{Ag}^{+} / \mathrm{Ag}$ ). The oxidation currents flow from this potential, which is attributed to the dissolution reaction of $\mathrm{Li}$ 
metal. We defined the zero-current potential as the redox potential of lithium $\left(=E\left(\mathrm{Li}^{+} / \mathrm{Li}\right)\right)$ and cathodic limit of this electrolyte, i.e. $E_{\mathrm{CL}}=E\left(\mathrm{Li}^{+} / \mathrm{Li}\right)$.

The $E_{\mathrm{CL}}$ values of the alkali metal-ion systems are more negative than that of pure $\left[\mathrm{C}_{4} \mathrm{C}_{1}\right.$ pyrr][FTA] (Table 3), which indicates that the addition of M[FTA] salts suppresses the decomposition of the organic $\mathrm{C}_{4} \mathrm{C}_{1}$ pyrr ${ }^{+}$cation. A similar $\mathrm{EW}$ widening was reported for the Li[FTA]-[C $\mathrm{C}_{2 \mathrm{O} 1} \mathrm{C}_{1}$ pyrr][FTA] IL. ${ }^{15}$ The redox potentials of the alkali metals (V vs. $\mathrm{Ag}^{+} / \mathrm{Ag}$ ) increases as follows: $\mathrm{Cs}(-3.83)<\mathrm{Rb}(-3.71)<\mathrm{K}(-3.67)<\mathrm{Li}(-3.48)<\mathrm{Na}(-3.36)$. Thus, Cs[FTA $]-\left[\mathrm{C}_{4} \mathrm{C}_{1}\right.$ pyrr $][\mathrm{FTA}]$ and $\mathrm{Na}[\mathrm{FTA}]-\left[\mathrm{C}_{4} \mathrm{C}_{1}\right.$ pyrr][FTA $]$ present the widest $(5.74 \mathrm{~V})$ and narrowest $(5.33 \mathrm{~V})$ EWs of all M[FTA]-[C ${ }_{4} \mathrm{C}_{1}$ pyrr] $[\mathrm{FTA}]$ ILs. In one of our previous studies, we determined that the redox potentials of lithium, sodium, and potassium of the $\left[\mathrm{C}_{3} \mathrm{C}_{1}\right.$ pyrr][FSA] ILs presented a similar trend, i.e. $E\left(\mathrm{~K}^{+} / \mathrm{K}\right)$ was more negative than $E\left(\mathrm{Na}^{+} / \mathrm{Na}\right)$ and $E\left(\mathrm{Li}^{+} / \mathrm{Li}\right)$ (see Table $\mathrm{S} 7)^{2}$

The coulombic efficiencies of the alkali metal deposition-dissolution reactions are provided in Table 3. Although the Li-, K-, and Cs-based ILs exhibited initial coulombic efficiencies of over $70 \%$, the coulombic efficiencies of the $\mathrm{Na}$ - and Rb-based ILs are as low as approximately $30 \%$. Such poor reversibility of the Na metal deposition-dissolution reaction has been reported in previous articles on FSA-based electrolytes $;^{2}$ however, the origin of these behaviors has not been elucidated. Because only a few comprehensive studies on the alkali metal deposition-dissolution have been conducted, including studies on $\mathrm{Rb}$ - and Cs-based electrolytes, it is necessary to continue to gather information on various electrolytes.

The trends in the redox potentials of alkali metals $\left(E\left(\mathrm{M}^{+} / \mathrm{M}\right)\right)$ are further compared among common electrolytes based on PC, acetonitrile (MeCN), water, ethanol (EtOH), $N, N$-dimethylformamide (DMF), $N$-methylpyrrolidone (NMP) and dimethyl sulfoxide (DMSO) 
solvents. Table $\mathrm{S} 7$ summarizes the $E\left(\mathrm{M}^{+} / \mathrm{M}\right)$ values with respect to the redox potentials of silver $\left(E\left(\mathrm{Ag}^{+} / \mathrm{Ag}\right)\right)$ in these electrolytes. The potentials for aqueous and organic solvent electrolytes were thermodynamically calculated, and not determined via electrochemical measurements. ${ }^{10}$ Moreover, the redox potentials of the $\mathrm{Ag}^{+} / \mathrm{Ag}$ couple listed in Table S7 were measured or calculated for each electrolyte. Because $E\left(\mathrm{Ag}^{+} / \mathrm{Ag}\right)$ varies depending on electrolyte, the $E\left(\mathrm{M}^{+} / \mathrm{M}\right)$ values in one electrolyte cannot be directly compared with those in other electrolytes.

Although the silver redox couple $\left(\mathrm{Ag}^{+} / \mathrm{Ag}\right)$ is commonly used as a reference electrode for various electrochemical measurements, the comparison of $E\left(\mathrm{M}^{+} / \mathrm{M}\right)$ with $E\left(\mathrm{Li}^{+} / \mathrm{Li}\right)$ is very important for predicting and evaluating the electrolyte properties of novel batteries. Fig. 7 illustrates the redox potentials of alkali metals $\left(E\left(\mathrm{M}^{+} / \mathrm{M}\right)\right)$ with respect to that of lithium $\left(E\left(\mathrm{Li}^{+} / \mathrm{Li}\right)\right)$. The $E\left(\mathrm{Na}^{+} / \mathrm{Na}\right)$ values are the most positive of all $E\left(\mathrm{M}^{+} / \mathrm{M}\right)$ values for all electrolytes. For the FTA-based ILs, $E\left(\mathrm{M}^{+} / \mathrm{M}\right)$ values $\left(\mathrm{V}\right.$ vs. $\left.\mathrm{Li}^{+} / \mathrm{Li}\right)$ increase as follows: $\mathrm{Cs}(-0.35)<\mathrm{Rb}$ $(-0.23)<\mathrm{K}(-0.19)<\mathrm{Li}(0)<\mathrm{Na}(0.12) . E\left(\mathrm{Cs}^{+} / \mathrm{Cs}\right)$ in the FTA-based ILs is the most negative of all the $E\left(\mathrm{M}^{+} / \mathrm{M}\right)$ values for all the electrolytes we compare. As mentioned above, the $E\left(\mathrm{M}^{+} / \mathrm{M}\right)$ values $(\mathrm{M}=\mathrm{K}, \mathrm{Na}, \mathrm{Li})$ of the FSA-based ILs present the same trend as those of the FTA-based ILs. Moreover, some organic solvents, such as $\mathrm{PC}$ and $\mathrm{MeCN}$, present a similar trend. For example, $E\left(\mathrm{M}^{+} / \mathrm{M}\right)$ values $\left(\mathrm{V}\right.$ vs. $\left.\mathrm{Li}^{+} / \mathrm{Li}\right)$ in $\mathrm{PC}$ increase as follows: $\mathrm{Cs}(-0.31)<\mathrm{Rb}(-0.16)<\mathrm{K}(-0.09)<\mathrm{Li}$ (0) $<\mathrm{Na}(0.23)$.

Conversely, the $E\left(\mathrm{Li}^{+} / \mathrm{Li}\right)$ values in aqueous solution and other organic solvent-based electrolytes are the most negative. The $E\left(\mathrm{M}^{+} / \mathrm{M}\right)$ values $\left(\mathrm{Vvs.} \mathrm{Li}^{+} / \mathrm{Li}\right)$ in aqueous solution increase as follows: $\mathrm{Li}(0)<\mathrm{Cs}(0.013)<\mathrm{Rb}(0.097)<\mathrm{K}(0.104)<\mathrm{Na}(0.326)$. The operating voltages of the alkali metal-ion batteries is an important parameter; however, the maximum operating voltages of alkali metal-ion batteries are limited within the EWs of the electrolytes. When the $E_{\mathrm{AL}}$ values of 
the electrolytes with different alkali metal cations are the same, the magnitude of the so-called maximum operating voltage of the alkali metal-ion batteries $\left(V_{\max }\right)$ is directly affected by the $E\left(\mathrm{M}^{+} / \mathrm{M}\right)$ values. According to their $E\left(\mathrm{M}^{+} / \mathrm{M}\right)$ values in aqueous solutions, LIBs are sometimes considered to be the highest-voltage batteries; however, the trend in the $E\left(\mathrm{M}^{+} / \mathrm{M}\right)$ values largely depends on the electrolyte. If the $E\left(\mathrm{M}^{+} / \mathrm{M}\right)$ values in aqueous solutions are used, the $V_{\max }$ values of the NIB and KIB are lower than that of the LIB by 0.326 and $0.104 \mathrm{~V}$, respectively. In contrast, for the FTA-based ILs, the $V_{\max }$ values of the KIB and NIB are $0.19 \mathrm{~V}$ higher and $0.12 \mathrm{~V}$ lower, respectively, than that of the LIB. As presented in Fig. 7, the $E\left(\mathrm{Na}^{+} / \mathrm{Na}\right)$ and $E\left(\mathrm{~K}^{+} / \mathrm{K}\right)$ values are the most negative in the FTA- and FSA-based ILs. Thus, according to their $V_{\max }$ values, these ILs are most advantageous as NIB and KIB electrolytes.

\section{CONCLUSIONS}

In this study, we compared FTA-based ILs with alkali metal cation charge carriers as alkali metal-ion battery electrolytes. The physicochemical properties of pure $\left[\mathrm{C}_{4} \mathrm{C}_{1}\right.$ pyrr $][\mathrm{FTA}]$ and $\mathrm{M}[\mathrm{FTA}]-\left[\mathrm{C}_{4} \mathrm{C}_{1}\right.$ pyrr $][\mathrm{FTA}] \mathrm{ILs}(x(\mathrm{M}[\mathrm{FTA}])=0.20 ; \mathrm{M}=\mathrm{Li}, \mathrm{Na}, \mathrm{K}, \mathrm{Rb}, \mathrm{Cs})$ with alkali metal-ion concentrations of approximately $0.8 \mathrm{~mol} \mathrm{dm}^{-3}$ presented several trends. Most ILs, except for the Li-based ILs, presented only supercooling behavior during the DSC measurements, and that was beneficial for the construction of batteries with wide temperature operating windows. The $\eta, \sigma$, and $\rho$ values of the FTA-based ILs were measured over a wide temperature range of 273-368 K. The temperature dependences of both $\eta$ and $\sigma$ obeyed the VTF equations. The orders of magnitude of the $\sigma$ values at $298 \mathrm{~K}$ were explained by the charge densities of the alkali metal cations for all systems except for the Li-based system. The Walden plots of the FTA-based ILs were well fitted with the fractional Walden rule, in which the $C^{\prime}$ value of the Li-based IL was slightly lower than 
those of the other alkali metal-based ILs. The obtained Walden plot parameters of the FTA-based ILs were compared with those of ILs and molten salts with other amide anions, viz. FSA ${ }^{-}$and TFSA $^{-}$. Cyclic voltammetry experiments revealed that the $E\left(\mathrm{M}^{+} / \mathrm{M}\right)$ values increased as follows: Cs $<\mathrm{Rb}<\mathrm{K}<\mathrm{Li}<\mathrm{Na}$, and the Cs-based IL presented the widest electrochemical window of all FTA-based ILs. Lastly, the trend in the $E\left(\mathrm{M}^{+} / \mathrm{M}\right)$ values in the FTA-based ILs was compared with those in other electrolytes. Although the trends in the $E\left(\mathrm{M}^{+} / \mathrm{M}\right)$ values in the FTA-based ILs and PC-based electrolytes were similar, the trend in aqueous solutions was entirely different. In particular, the FTA- and FSA-based ILs presented the most negative $E\left(\mathrm{Na}^{+} / \mathrm{Na}\right)$ and $E\left(\mathrm{~K}^{+} / \mathrm{K}\right)$ values among the analyzed electrolytes. Thus, the use of these IL electrolytes for the development of NIBs and KIBs present significant advantages.

\section{- ASSOCIATED CONTENT}

Supporting Information

Viscosities, ionic conductivities, densities, molar concentrations, molar ionic conductivities, Vogel-Tammann-Fulcher parameters, redox potentials of alkali metals in various electrolytes, and differential scanning calorimetry curves (PDF)

\section{- AUTHOR INFORMATION}

Corresponding Authors

*E-mail: yamamoto.takayuki.2w@kyoto-u.ac.jp, Tel: +81-774-38-3498, Fax: +81-774-38-3499 (T.Y.)

*E-mail: nohira.toshiyuki.8r@kyoto-u.ac.jp, Tel: +81-774-38-3500, Fax: +81-774-38-3499 (T.N.) 
Notes

The authors declare no competing financial interest.

\section{- ACKNOWLEDGMENTS}

This study was partly supported by a JSPS KAKENHI grant (JP18K14320) and a research grant from the Foundation for the Promotion of Ion Engineering. 


\section{- REFERENCES}

(1) Hagiwara, R.; Matsumoto, K.; Hwang, J.; Nohira, T. Sodium Ion Batteries using Ionic Liquids as Electrolytes. Chem. Rec. 2018, 18, 1-14.

(2) Yamamoto, T.; Matsumoto, K.; Hagiwara, R.; Nohira, T. Physicochemical and Electrochemical Properties of $\mathrm{K}\left[\mathrm{N}\left(\mathrm{SO}_{2} \mathrm{~F}\right)_{2}\right]-[\mathrm{N}-$ Methyl-N-propylpyrrolidinium $]\left[\mathrm{N}\left(\mathrm{SO}_{2} \mathrm{~F}\right)_{2}\right]$ Ionic Liquids for Potassium-Ion Batteries. J. Phys. Chem. C 2017, 121, 18450-18458.

(3) Yamamoto, T.; Nohira, T. Tin negative electrodes using an FSA-based ionic liquid electrolyte: improved performance of potassium secondary batteries. Chem. Comm. 2020, 56, $2538-2541$.

(4) Larcher, D.; Tarascon, J. M. Towards Greener and More Sustainable Batteries for Electrical Energy Storage. Nat. Chem. 2015, 7, 19-29.

(5) Yabuuchi, N.; Kubota, K.; Dahbi, M.; Komaba, S. Research Development on Sodium-Ion Batteries. Chem. Rev. 2014, 114, 11636-11682.

(6) Eftekhari, A.; Jian, Z.; Ji, X. Potassium Secondary Batteries. ACS Appl. Mater. Interfaces 2017, 9, 4404-4419.

(7) Kubota, K.; Dahbi, M.; Hosaka, T.; Kumakura, S.; Komaba, S. Towards K-Ion and Na-Ion Batteries as "Beyond Li-Ion”. Chem. Rec. 2018, 18, 1-22.

(8) Watanabe, M.; Thomas, M. L.; Zhang, S.; Ueno, K.; Yasuda, T.; Dokko, K. Application of Ionic Liquids to Energy Storage and Conversion Materials and Devices. Chem. Rev. 2017, $117,7190-7239$.

(9) Matsumoto, K.; Hwang, J.; Kaushik, S.; Chen, C.-Y.; Hagiwara, R. Advances in sodium secondary batteries utilizing ionic liquid electrolytes. Energy Environ. Sci. 2019, 12, 32473287. 
(10) Marcus, Y. Thermodynamic Functions of Transfer of Single Ions from Water to Nonaqueous and Mixed Solvents, PART 3: Standard Potentials of Selected Electrodes. Pure Appl. Chem. 1985, 57, 1129-1132.

(11) Matsumoto, H.; Terasawa, N.; Umecky, T.; Tsuzuki, S.; Sakaebe, H.; Asaka, K.; Tatsumi, K. Low Melting and Electrochemically Stable Ionic Liquids Based on Asymmetric Fluorosulfonyl(trifluoromethylsulfonyl)amide. Chem. Lett. 2008, 37, 1020-1021.

(12)Kubota, K.; Nohira, T.; Hagiwara, R.; Matsumoto, H. Thermal Properties of Alkali (Fluorosulfonyl)(trifluoromethylsulfonyl)amides. Chem. Lett. 2010, 39, 1303-1304.

(13) Jeong, S.; Li, S.; Appetecchi, G. B.; Passerini, S. Asymmetric ammonium-based ionic liquids as electrolyte components for safer, high-energy, electrochemical storage devices. Energy Storage Mater. 2019, 18, 1-9.

(14) Kubota, K.; Matsumoto, H. Investigation of an Intermediate Temperature Molten Lithium Salt Based on Fluorosulfonyl(trifluoromethylsulfonyl)amide as a Solvent-Free Lithium Battery Electrolyte. J. Phys. Chem. C 2013, 117, 18829-18836.

(15) Giffin, G. A.; Moretti, A.; Jeong, S.; Passerini, S. Decoupling effective $\mathrm{Li}^{+}$ion conductivity from electrolyte viscosity for improved room-temperature cell performance. J. Power Sources 2017, 342, 335-341.

(16) Yang, H.; Luo X.-F.; Matsumoto, K; Chang, J.-K.; Hagiwara, R. Physicochemical and electrochemical properties of the (fluorosulfonyl)(trifluoromethylsulfonyl)amide ionic liquid for Na secondary batteries. J. Power Sources 2020, 470, 228406.

(17) Zhou, Q.; Henderson, W. A.; Appetecchi, G. B.; Montanino, M.; Passerini, S. Physical and Electrochemical Properties of $N$-Alkyl- $N$-methylpyrrolidinium Bis(fluorosulfonyl)imide Ionic Liquids: PY ${ }_{13} \mathrm{FSI}$ and PY ${ }_{14} \mathrm{FSI}$. J. Phys. Chem. B 2008, 112, 13577-13580. 
(18) Easteal, A. J.; Angell, C. A. Viscosity of Molten $\mathrm{ZnCl}_{2}$ and Supercritical Behavior in Its Binary Solutions. J. Chem. Phys. 1972, 56, 4231-4233.

(19) Reiter, J.; Jeremias, S.; Paillard, E.; Winter, M.; Passerini, S. Fluorosulfonyl-(trifluoromethanesulfonyl)imide ionic liquids with enhanced asymmetry. Phys. Chem. Chem. Phys. 2013, 15, 2565-2571.

(20) Makino, T.; Kanakubo, M.; Umecky, T.; Suzuki, A.; Nishida, T.; Takano, J. Electrical Conductivities, Viscosities, and Densities of $N$-Methoxymethyl- and $N$-Butyl- $N$-methylpyrrolidinium Ionic Liquids with the Bis(fluorosulfonyl)amide Anion. $J$. Chem. Eng. Data 2012, 57, 751-755.

(21) Harris, K. R.; Woolf, L. A. Transport Properties of $N$-Butyl- $N$-methylpyrrolidinium Bis(trifluoromethylsulfonyl)amide. J. Chem. Eng. Data 2011, 56, 4672-4685.

(22)Kubota, K.; Tamaki, K.; Nohira, T.; Goto, T.; Hagiwara, R. Electrochemical properties of alkali bis(trifluoromethylsulfonyl)amides and their eutectic mixtures. Electrochim. Acta 2010, $55,1113-1119$.

(23) Komaba, S.; Hasegawa, T.; Dahbi, M.; Kubota, K. Potassium intercalation into graphite to realize high-voltage/high-power potassium-ion batteries and potassium-ion capacitors, Electrochem. Commun. 2015, 60, 172-175.

(24) Xu, W.; Cooper, E. I.; Angell, C. A. Ionic Liquids: Ion Mobilities, Glass Temperatures, and Fragilities. J. Phys. Chem. B 2003, 107, 6170-6178.

(25) Xu, W.; Angell, C. A. Solvent-Free Electrolytes with Aqueous Solution-Like Conductivities. Science 2003, 302, 422-425.

(26) Pugsley, F. A.; Westmore, F. E. W. Molten Salts: Viscosity of Silver Nitrate. Can. J. Chem. 1954, 32, 839-841. 
(27) Schreiner, C.; Zugmann, S.; Hartl, R.; Gores, H. J. Fractional Walden Rule for Ionic Liquids: Examples from Recent Measurements and a Critique of the So-Called Ideal $\mathrm{KCl}$ Line for the Walden Plot. J. Chem. Eng. Data 2010, 55, 1784-1788.

(28) Yoon, H.; Best, A. S.; Forsyth, M.; MacFarlane, D. R.; Howlett, P. C. Physical properties of high Li-ion content $N$-propyl- $N$-methylpyrrolidinium bis(fluorosulfonyl)imide based ionic liquid electrolytes. Phys. Chem. Chem. Phys. 2015, 17, 4656-4663.

(29) Matsumoto, K.; Okamoto, Y.; Nohira, T.; Hagiwara, R. Thermal and Transport Properties of $\mathrm{Na}\left[\mathrm{N}\left(\mathrm{SO}_{2} \mathrm{~F}\right)_{2}\right]-[N$-Methyl- $N$-propylpyrrolidinium $]\left[\mathrm{N}\left(\mathrm{SO}_{2} \mathrm{~F}\right)_{2}\right]$ Ionic Liquids for $\mathrm{Na}$ Secondary Batteries. J. Phys. Chem. C 2015, 119, 7648-7655.

(30) Tsuzuki, S.; Kubota, K.; Matsumoto, H. Cation and Anion Dependence of Stable Geometries and Stabilization Energies of Alkali Metal Cation Complexes with $\mathrm{FSA}^{-}, \mathrm{FTA}^{-}$, and TFSA Anions: Relationship with Physicochemical Properties of Molten Salts. J. Phys. Chem. B 2013, $117,16212-16218$. 


\section{- TABLES and FIGURES}

Table 1 Melting temperature and other physicochemical properties at $298 \mathrm{~K}$ of $\left[\mathrm{C}_{4} \mathrm{C}_{1}\right.$ pyrr][FTA] (Pure IL) and M[FTA] $-\left[\mathrm{C}_{4} \mathrm{C}_{1}\right.$ pyrr $][\mathrm{FTA}]$ ionic liquids (ILs) $(x(\mathrm{M}[\mathrm{FTA}])=0.20 ; \mathrm{M}=\mathrm{Li}, \mathrm{Na}, \mathrm{K}$, $\mathrm{Rb}, \mathrm{Cs})$.

\begin{tabular}{cccccc}
\hline IL & $\begin{array}{c}T_{\mathrm{m}} \\
/ \mathrm{K}\end{array}$ & $\begin{array}{c}\eta \\
\mathrm{mPa} \mathrm{s}\end{array}$ & $\begin{array}{c}\sigma \\
/ \mathrm{mS} \mathrm{cm}^{-1}\end{array}$ & $\begin{array}{c}\rho \\
/ \mathrm{g} \mathrm{cm}^{-3}\end{array}$ & $\begin{array}{c}C\left(\mathrm{M}^{+}\right) \\
/ \mathrm{mol} \mathrm{dm}^{-3}\end{array}$ \\
\hline Pure IL & n.d. & 51.0 & 4.4 & 1.357 & - \\
$\mathrm{M}=\mathrm{Li}$ & 262 & 117 & 2.0 & 1.416 & 0.820 \\
$\mathrm{M}=\mathrm{Na}$ & n.d. & 149 & 1.7 & 1.427 & 0.819 \\
$\mathrm{M}=\mathrm{K}$ & n.d. & 128 & 2.2 & 1.431 & 0.814 \\
$\mathrm{M}=\mathrm{Rb}$ & n.d. & 119 & 2.3 & 1.464 & 0.811 \\
$\mathrm{M}=\mathrm{Cs}$ & n.d. & 97.4 & 2.6 & 1.494 & 0.806 \\
\hline
\end{tabular}

$T_{\mathrm{m}}$ : end temperature of melting, $\eta$ : viscosity, $\sigma$ : ionic conductivity, $\rho$ : density, and $C\left(\mathrm{M}^{+}\right)$: molar concentration of alkali metal cation $\left(\mathrm{M}^{+}\right)$ 
Table 2 Summary of Walden plot parameters of different ionic liquids (ILs) and molten salts.

\begin{tabular}{|c|c|c|c|}
\hline IL & $\alpha$ & $C^{\prime}$ & Ref. \\
\hline$\left[\mathrm{C}_{4} \mathrm{C}_{1}\right.$ pyrr $][\mathrm{FTA}]$ & 0.93 & -0.19 & \multirow{6}{*}{ This study } \\
\hline $\mathrm{Li}[\mathrm{FTA}]-\left[\mathrm{C}_{4} \mathrm{C}_{1}\right.$ pyrr $][\mathrm{FTA}]$ & 0.94 & -0.25 & \\
\hline $\mathrm{Na}[\mathrm{FTA}]-\left[\mathrm{C}_{4} \mathrm{C}_{1}\right.$ pyrr $][\mathrm{FTA}]$ & 0.94 & -0.22 & \\
\hline $\mathrm{K}[\mathrm{FTA}]-\left[\mathrm{C}_{4} \mathrm{C}_{1}\right.$ pyrr $][\mathrm{FTA}]$ & 0.91 & -0.18 & \\
\hline $\mathrm{Rb}[\mathrm{FTA}]-\left[\mathrm{C}_{4} \mathrm{C}_{1}\right.$ pyrr $][\mathrm{FTA}]$ & 0.94 & -0.18 & \\
\hline $\mathrm{Cs}[\mathrm{FTA}]-\left[\mathrm{C}_{4} \mathrm{C}_{1}\right.$ pyrr $][\mathrm{FTA}]$ & 0.93 & -0.21 & \\
\hline$\left[\mathrm{C}_{4} \mathrm{C}_{1}\right.$ pyrr $][\mathrm{FSA}]$ & 0.913 & -0.067 & 20 \\
\hline$\left[\mathrm{C}_{4} \mathrm{C}_{1}\right.$ pyrr $][\mathrm{TFSA}]$ & 0.924 & -0.180 & 21 \\
\hline Li[TFSA] & 0.845 & -0.381 & 22 \\
\hline $\mathrm{Na}$ [TFSA] & 0.844 & -0.118 & 22 \\
\hline $\mathrm{K}[\mathrm{TFSA}]$ & 0.861 & 0.009 & 22 \\
\hline $\mathrm{Rb}[\mathrm{TFSA}]$ & 0.908 & -0.034 & 22 \\
\hline $\mathrm{Cs}[\mathrm{TFSA}]$ & 0.900 & -0.070 & 22 \\
\hline
\end{tabular}


Table 3 Cathodic $\left(E_{\mathrm{CL}}\right)$ and anodic $\left(E_{\mathrm{AL}}\right)$ limit potentials, electrochemical windows $(\mathrm{EW})$, and coulombic efficiencies of the alkali metal deposition-dissolution cycle during the first cycle ( $\left.\eta_{1 \mathrm{st}}\right)$

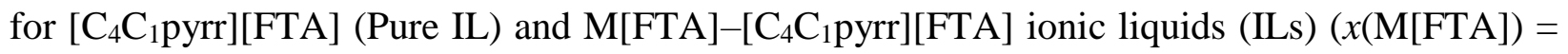
$0.20 ; \mathrm{M}=\mathrm{Li}, \mathrm{Na}, \mathrm{K}, \mathrm{Rb}, \mathrm{Cs})$.

\begin{tabular}{ccccc}
\hline & \multicolumn{2}{c}{ Limit potential / V vs. $\mathrm{Ag}^{+} / \mathrm{Ag}$} & EW / V & $\eta_{\text {1st }} / \%$ \\
\cline { 2 - 3 } & $E_{\mathrm{CL}}$ & $E_{\mathrm{AL}}$ & & $\mathrm{n} / \mathrm{a}$ \\
\cline { 1 - 3 } Pure IL & $-2.98^{a}$ & $1.96^{a}$ & 4.94 & 76 \\
$\mathrm{M}=\mathrm{Li}$ & $-3.48^{b}$ & $1.97^{a}$ & 5.45 & 30 \\
$\mathrm{M}=\mathrm{Na}$ & $-3.36^{b}$ & $1.97^{a}$ & 5.33 & 71 \\
$\mathrm{M}=\mathrm{K}$ & $-3.67^{b}$ & $1.91^{a}$ & 5.58 & 29 \\
$\mathrm{M}=\mathrm{Rb}$ & $-3.71^{b}$ & $1.93^{a}$ & 5.64 & 75 \\
$\mathrm{M}=\mathrm{Cs}$ & $-3.83^{b}$ & $1.91^{a}$ & 5.74 & 75 \\
\hline
\end{tabular}

${ }^{a}$ The $E_{\mathrm{CL}}$ values of the pure IL and $E_{\mathrm{AL}}$ values of all ILs were determined as the potentials at which the current density during the cathodic and anodic sweep reaches -0.1 and $0.1 \mathrm{~mA} \mathrm{~cm}^{-2}$, respectively.

${ }^{b}$ The $E_{\mathrm{CL}}$ values of the M[FTA]-[C $\mathrm{C}_{4} \mathrm{C}_{1}$ pyrr][FTA] ILs are defined as the zero-current potentials in their cyclic voltammograms. $\left(E_{\mathrm{CL}}=E\left(\mathrm{M}^{+} / \mathrm{M}\right)\right)$ 


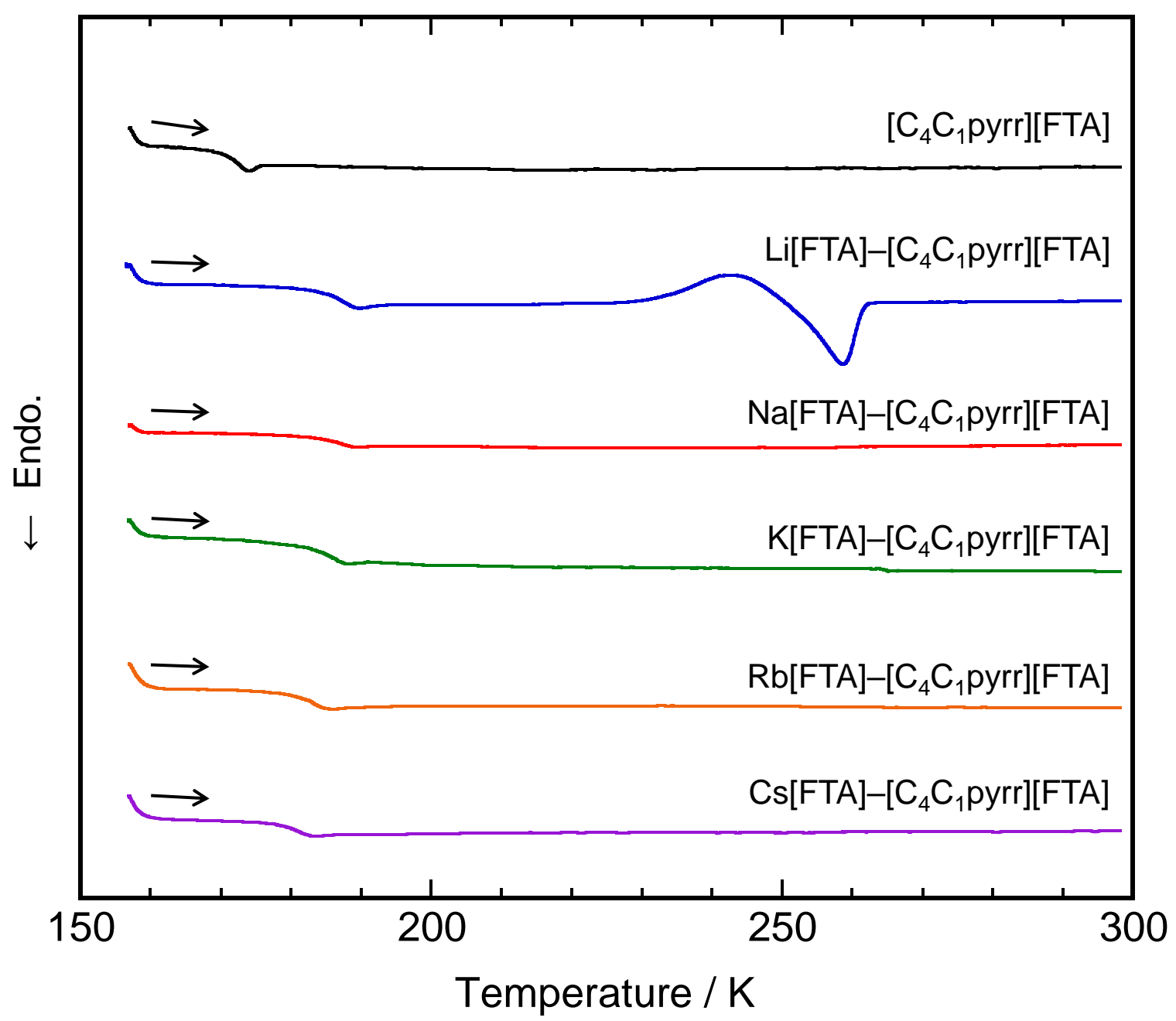

Fig. 1 Differential scanning calorimetry curves of $\left[\mathrm{C}_{4} \mathrm{C}_{1}\right.$ pyrr $][\mathrm{FTA}]$ and $\mathrm{M}[\mathrm{FTA}]-$ $\left[\mathrm{C}_{4} \mathrm{C}_{1}\right.$ pyrr $][\mathrm{FTA}]$ ionic liquids $(x(\mathrm{M}[\mathrm{FTA}])=0.20 ; \mathrm{M}=\mathrm{Li}, \mathrm{Na}, \mathrm{K}, \mathrm{Rb}, \mathrm{Cs})$ at a scan rate of $2 \mathrm{~K}$ $\min ^{-1}$. 


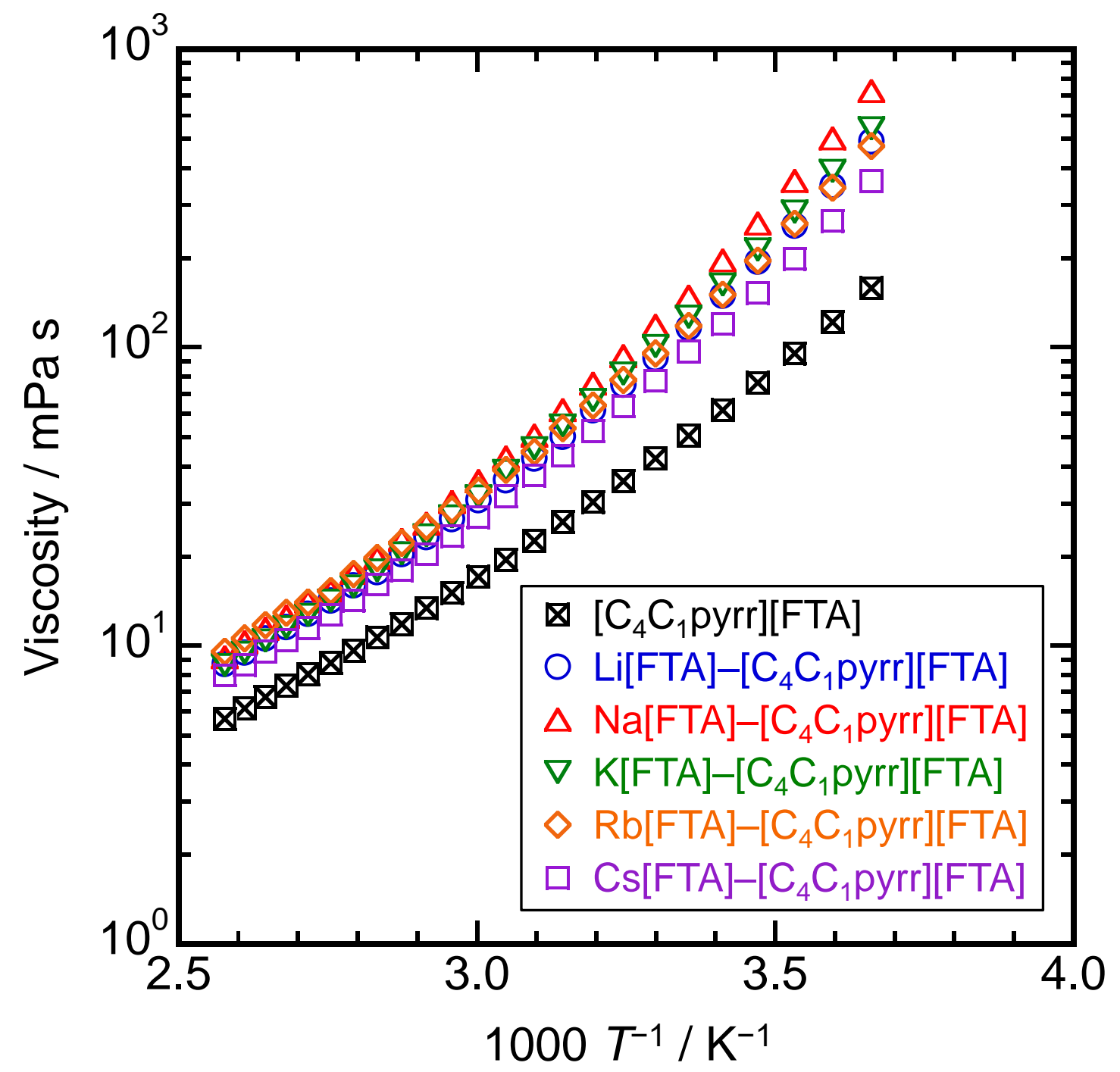

Fig. 2 Arrhenius plots of viscosities for $\left[\mathrm{C}_{4} \mathrm{C}_{1}\right.$ pyrr][FTA] and $\mathrm{M}[\mathrm{FTA}]-\left[\mathrm{C}_{4} \mathrm{C}_{1}\right.$ pyrr][FTA] $(x(\mathrm{M}[\mathrm{FTA}])=0.20 ; \mathrm{M}=\mathrm{Li}, \mathrm{Na}, \mathrm{K}, \mathrm{Rb}, \mathrm{Cs})$ ionic liquids. 


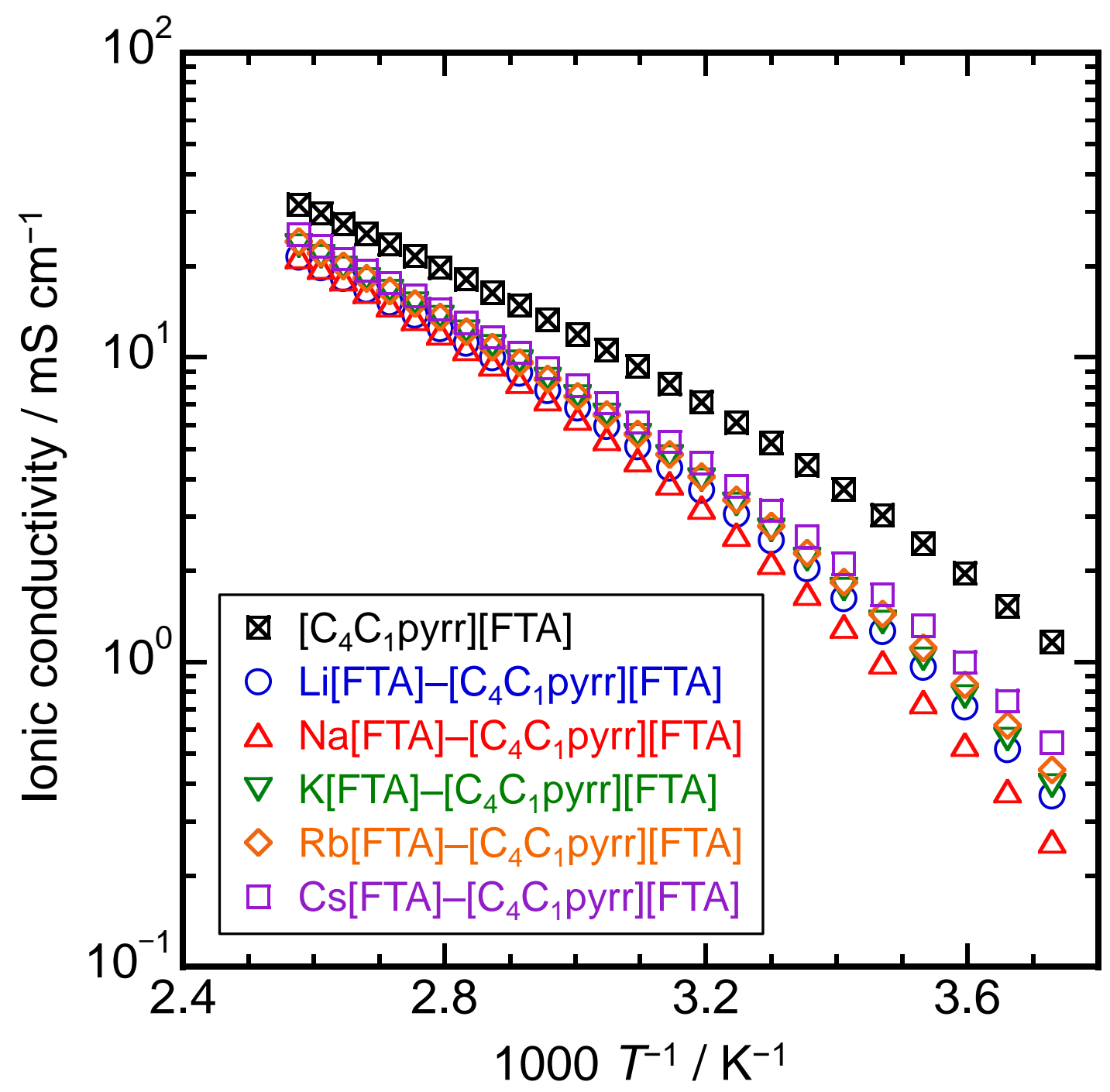

Fig. 3 Arrhenius plots of ionic conductivities for $\left[\mathrm{C}_{4} \mathrm{C}_{1}\right.$ pyrr $][\mathrm{FTA}]$ and $\mathrm{M}[\mathrm{FTA}]-\left[\mathrm{C}_{4} \mathrm{C}_{1}\right.$ pyrr $][\mathrm{FTA}]$ $(x(\mathrm{M}[\mathrm{FTA}])=0.20 ; \mathrm{M}=\mathrm{Li}, \mathrm{Na}, \mathrm{K}, \mathrm{Rb}, \mathrm{Cs})$ ionic liquids. 


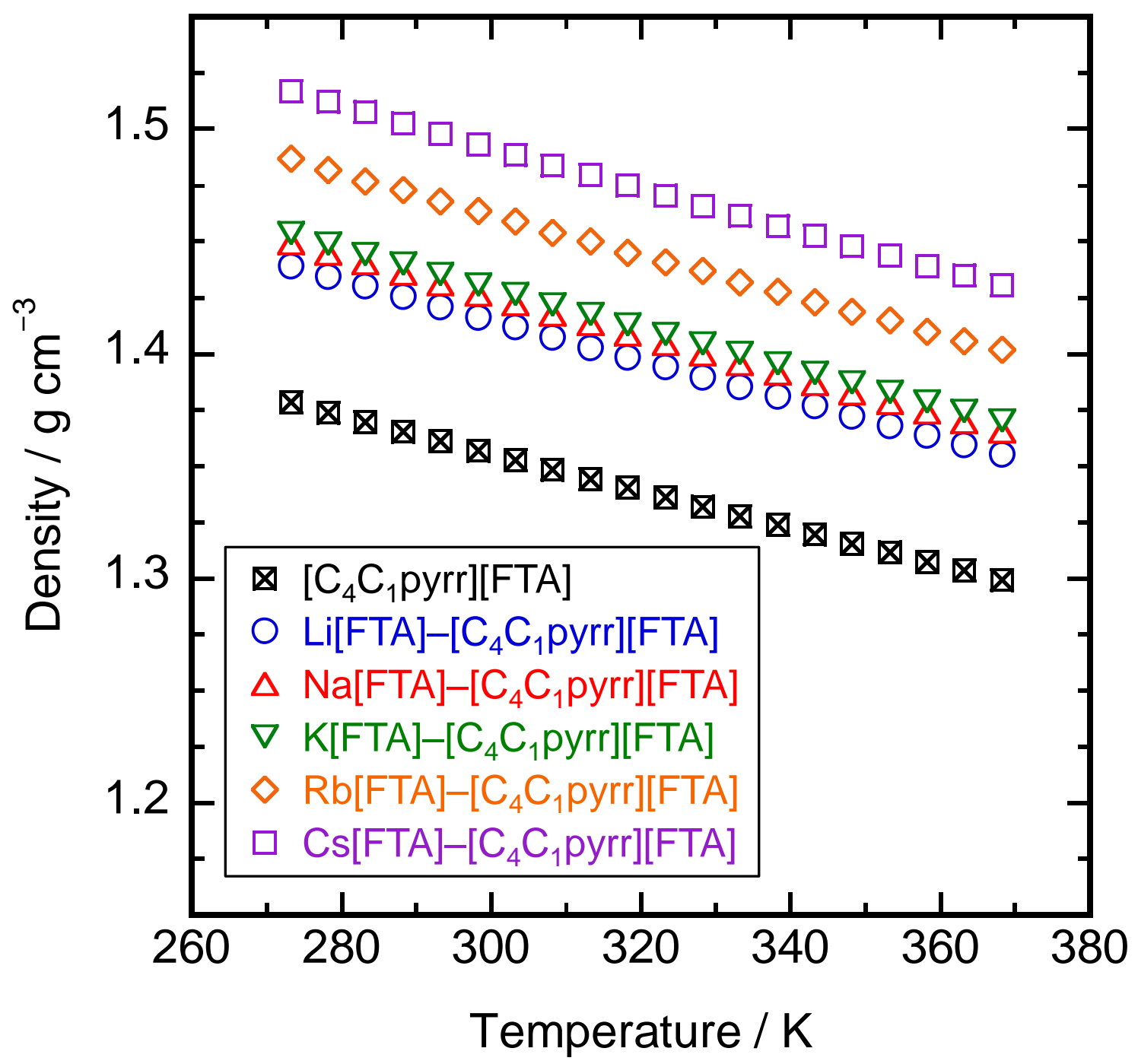

Fig. 4 Density plots of $\left[\mathrm{C}_{4} \mathrm{C}_{1}\right.$ pyrr $][\mathrm{FTA}]$ and $\mathrm{M}[\mathrm{FTA}]-\left[\mathrm{C}_{4} \mathrm{C}_{1}\right.$ pyrr $][\mathrm{FTA}](x(\mathrm{M}[\mathrm{FTA}])=0.20 ; \mathrm{M}=$ $\mathrm{Li}, \mathrm{Na}, \mathrm{K}, \mathrm{Rb}, \mathrm{Cs}$ ) ionic liquids. 


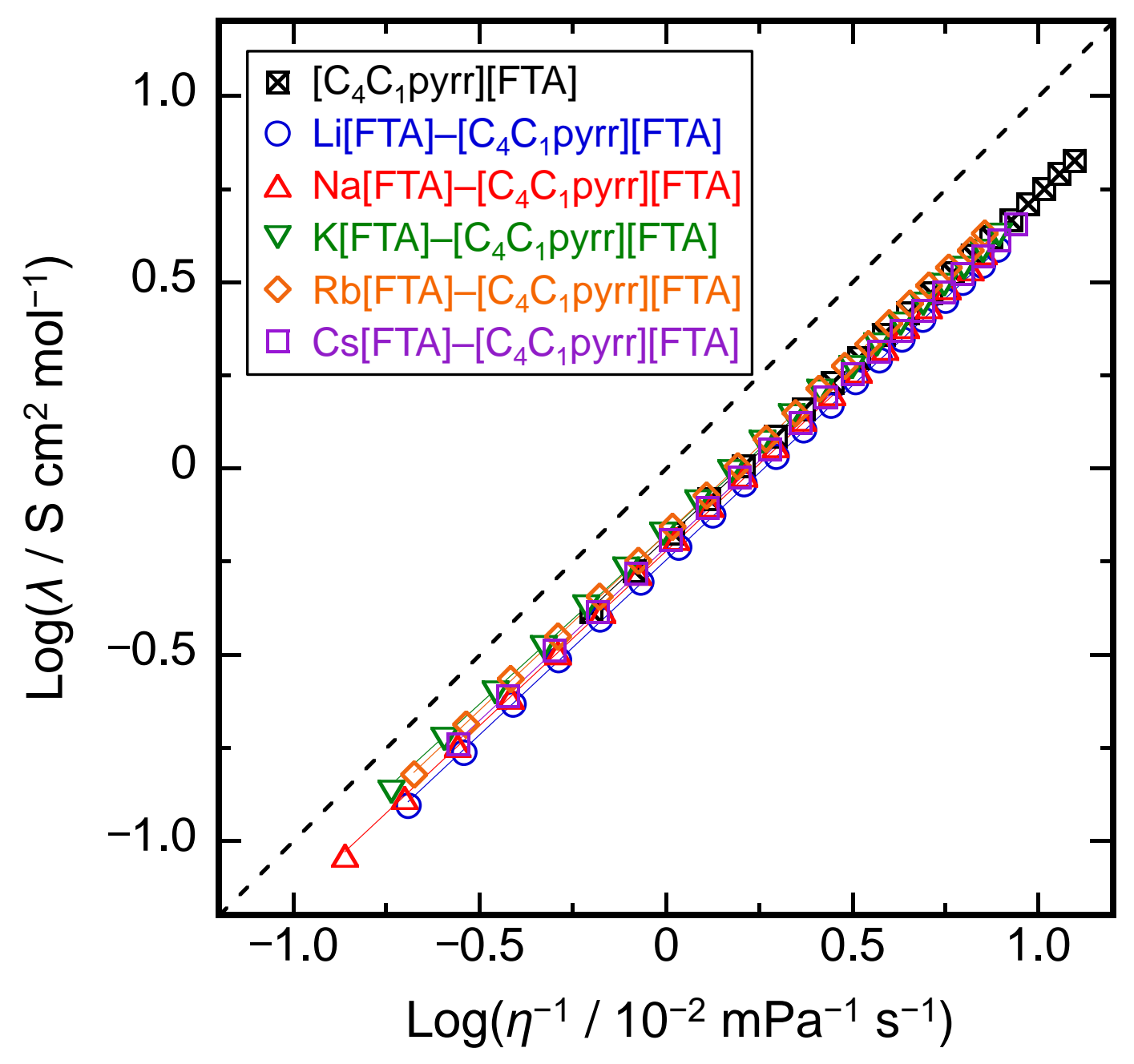

Fig. 5 Walden plots of $\left[\mathrm{C}_{4} \mathrm{C}_{1}\right.$ pyrr $][\mathrm{FTA}]$ and $\mathrm{M}[\mathrm{FTA}]-\left[\mathrm{C}_{4} \mathrm{C}_{1}\right.$ pyrr $][\mathrm{FTA}](x(\mathrm{M}[\mathrm{FTA}])=0.20 ; \mathrm{M}=$ $\mathrm{Li}, \mathrm{Na}, \mathrm{K}, \mathrm{Rb}, \mathrm{Cs}$ ) ionic liquids. The ideal $\mathrm{KCl}$ line is indicated by a dashed line. 


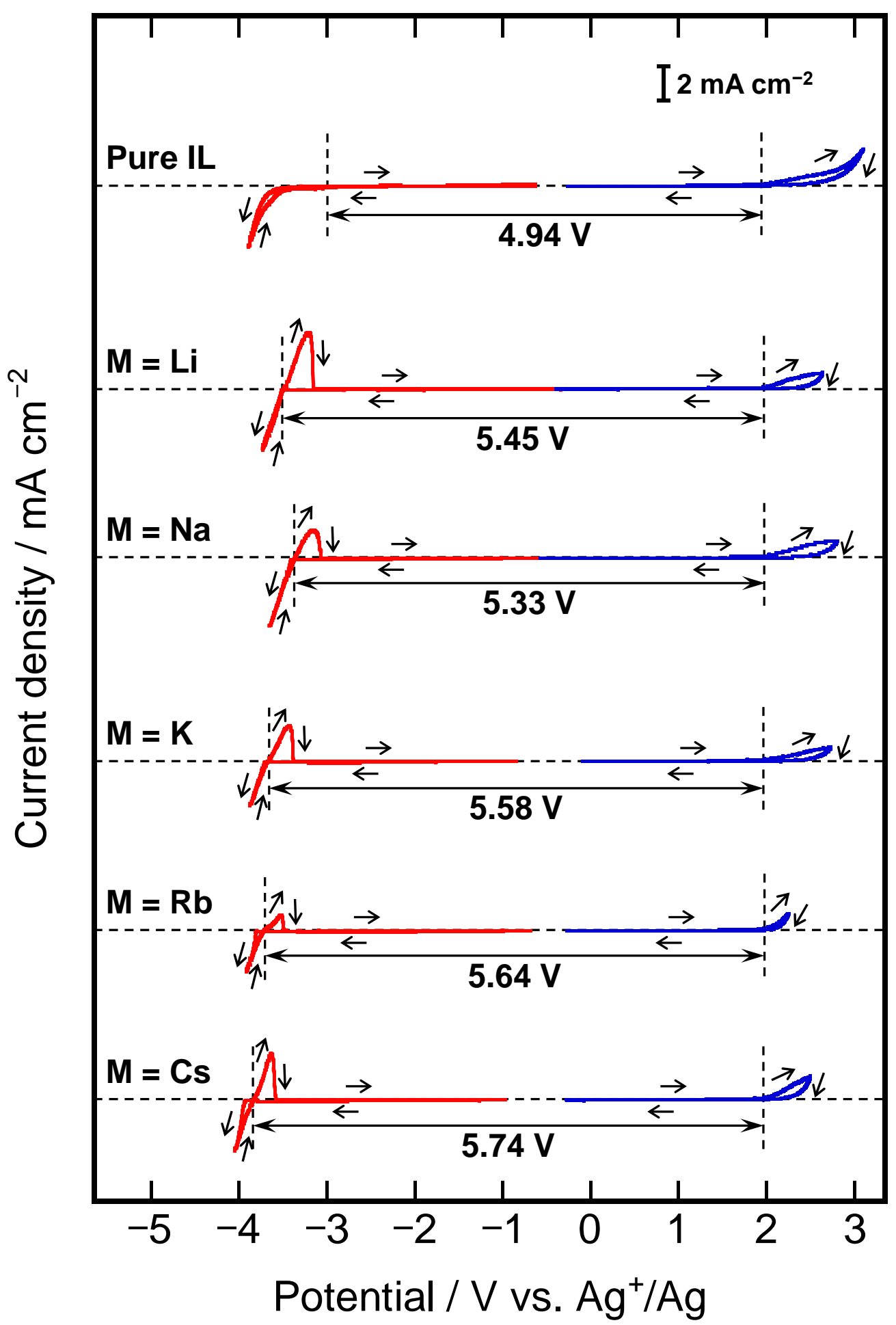

Fig. 6 Cyclic voltammograms of $\left[\mathrm{C}_{4} \mathrm{C}_{1}\right.$ pyrr][FTA] (Pure IL) and $\mathrm{M}[\mathrm{FTA}]-\left[\mathrm{C}_{4} \mathrm{C}_{1}\right.$ pyrr][FTA] $(x(\mathrm{M}[\mathrm{FTA}])=0.20 ; \mathrm{M}=\mathrm{Li}, \mathrm{Na}, \mathrm{K}, \mathrm{Rb}, \mathrm{Cs})$ ionic liquids (ILs) at $298 \mathrm{~K}$. Working electrodes: $\mathrm{Cu}$ and glassy carbon disk (negative and positive potential regions, respectively). Scan rate: $5 \mathrm{mV} \mathrm{s}^{-1}$. Cycle number: 1st. The cathodic and anodic limits of each electrolyte are indicated by vertical dashed lines. The zero-current density of each electrolyte is illustrated as a horizontal dashed line. 


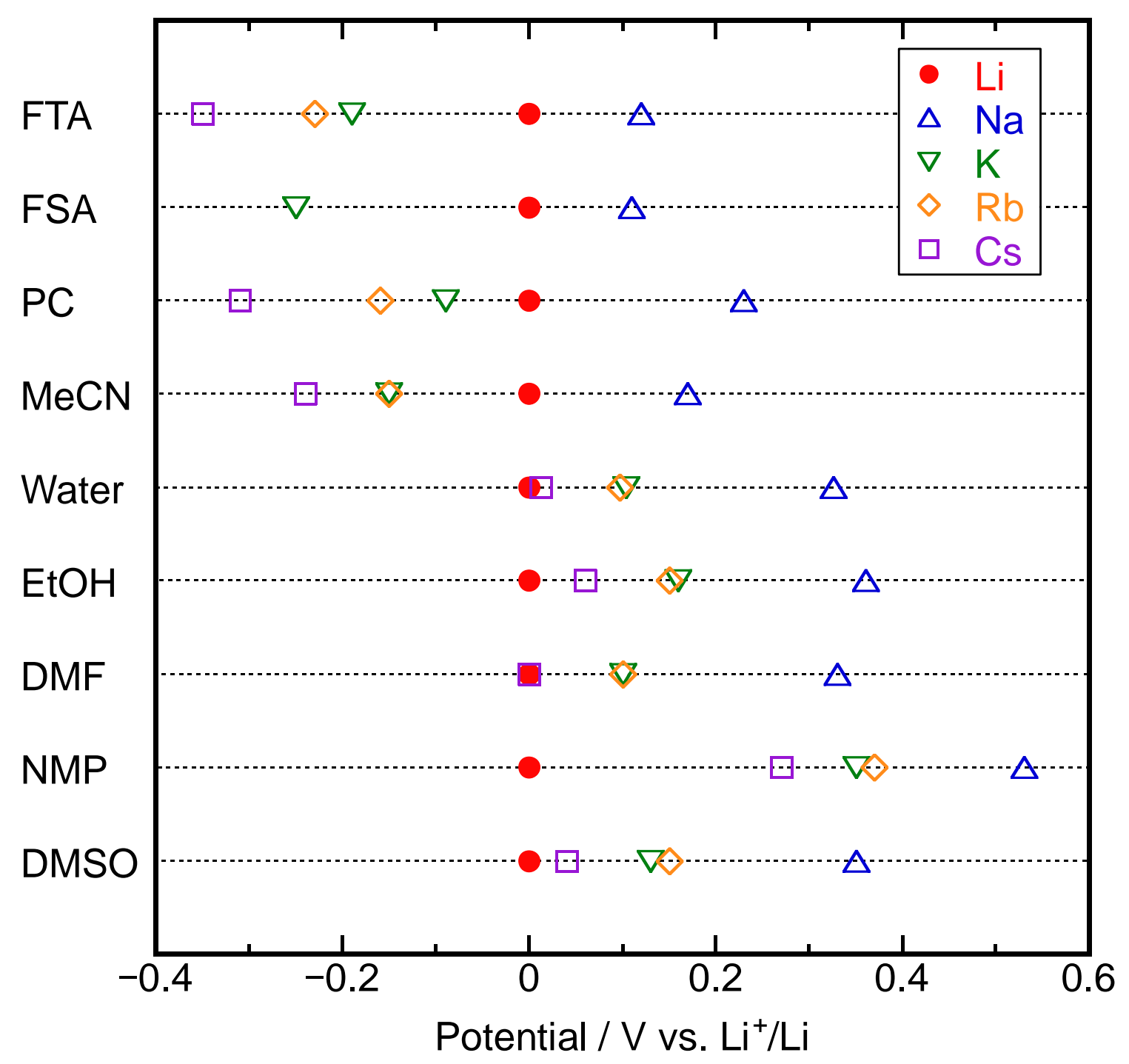

Fig. 7 Redox potentials of alkali metals $\left(E\left(\mathrm{M}^{+} / \mathrm{M}\right) ; \mathrm{M}=\right.$ alkali metal $)$ in various electrolytes with respect to $E\left(\mathrm{Li}^{+} / \mathrm{Li}\right)$. FTA $=\mathrm{M}[\mathrm{FTA}]-\left[\mathrm{C}_{4} \mathrm{C}_{1}\right.$ pyrr] $[\mathrm{FTA}]\left(C\left(\mathrm{Li}^{+}\right)=0.820 \mathrm{~mol} \mathrm{dm}^{-3}, C\left(\mathrm{Na}^{+}\right)=0.819\right.$ $\left.\mathrm{mol} \mathrm{dm}{ }^{-3}, C\left(\mathrm{~K}^{+}\right)=0.814 \mathrm{~mol} \mathrm{dm}^{-3}, C\left(\mathrm{Rb}^{+}\right)=0.811 \mathrm{~mol} \mathrm{dm}^{-3}, C\left(\mathrm{Cs}^{+}\right)=0.806 \mathrm{~mol} \mathrm{dm}^{-3}\right)$, FSA $=$ M[FSA]-[C $\mathrm{C}_{3} \mathrm{C}_{1}$ pyrr][FSA] $\left(C\left(\mathrm{Li}^{+}\right)=1.0 \mathrm{~mol} \mathrm{dm}{ }^{-3},{ }^{28} C\left(\mathrm{Na}^{+}\right)=0.98 \mathrm{~mol} \mathrm{dm}{ }^{-3}{ }^{29} C\left(\mathrm{~K}^{+}\right)=0.98 \mathrm{~mol}\right.$ $\left.\mathrm{dm}^{-3}\right),{ }^{2} \mathrm{PC}=$ propylene carbonate $\left(C\left(\mathrm{M}^{+}\right)=1 \mathrm{~mol} \mathrm{dm}^{-3}\right), \mathrm{MeCN}=$ acetonitrile $\left(C\left(\mathrm{M}^{+}\right)=1 \mathrm{~mol}\right.$ $\left.\mathrm{dm}^{-3}\right), \mathrm{EtOH}=$ ethanol $\left(C\left(\mathrm{M}^{+}\right)=1 \mathrm{~mol} \mathrm{dm}{ }^{-3}\right), \mathrm{DMF}=N, N$-dimethylformamide $\left(C\left(\mathrm{M}^{+}\right)=1 \mathrm{~mol}\right.$ $\left.\mathrm{dm}^{-3}\right), \mathrm{NMP}=N$-methylpyrrolidone $\left(C\left(\mathrm{M}^{+}\right)=1 \mathrm{~mol} \mathrm{dm}^{-3}\right), \mathrm{DMSO}=$ dimethyl sulfoxide $\left(C\left(\mathrm{M}^{+}\right)=\right.$ $1 \mathrm{~mol} \mathrm{dm}^{-3}$ ). 


\section{TOC graphic}

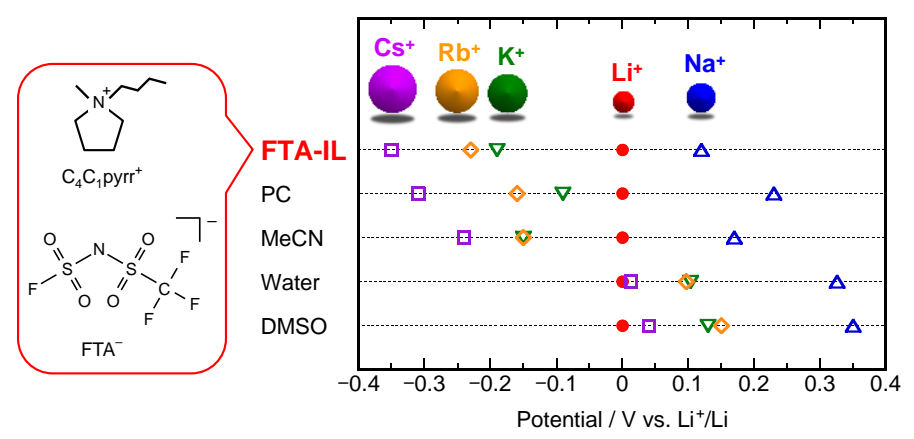




\section{Supporting Information}

\section{Comparative Study of $\mathrm{M}\left[\mathrm{N}\left(\mathrm{SO}_{2} \mathrm{~F}\right)\left(\mathrm{SO}_{2} \mathrm{CF}_{3}\right)\right]-[N$-butyl-}

$N$-methylpyrroridinium $]\left[\mathrm{N}\left(\mathrm{SO}_{2} \mathrm{~F}\right)\left(\mathrm{SO}_{2} \mathrm{CF}_{3}\right)\right](\mathrm{M}=\mathrm{Li}$, $\mathrm{Na}, \mathrm{K}, \mathrm{Rb}, \mathrm{Cs}$ ) Ionic Liquid Electrolytes

Takayuki Yamamoto,* Shu Nishijima, and Toshiyuki Nohira*

Institute of Advanced Energy, Kyoto University, Uji 611-0011, Japan

Corresponding Authors

*E-mail: yamamoto.takayuki.2w@kyoto-u.ac.jp, Tel: +81-774-38-3498, Fax: +81-774-383499 (T. Y.)

*E-mail: nohira.toshiyuki.8r@kyoto-u.ac.jp, Tel: +81-774-38-3500, Fax: +81-774-38-3499 (T. N.) 
Table S1 Viscosities (mPa s) of $\left[\mathrm{C}_{4} \mathrm{C}_{1}\right.$ pyrr] [FTA] (Pure IL) and $\mathrm{M}[\mathrm{FTA}]-\left[\mathrm{C}_{4} \mathrm{C}_{1}\right.$ pyrr][FTA] ionic liquids $(x(\mathrm{M}[\mathrm{FTA}])=0.20 ; \mathrm{M}=\mathrm{Li}, \mathrm{Na}, \mathrm{K}, \mathrm{Rb}, \mathrm{Cs})$.

\begin{tabular}{|c|c|c|c|c|c|c|}
\hline$T / \mathrm{K}$ & Pure IL & $\mathrm{M}=\mathrm{Li}$ & $\mathrm{M}=\mathrm{Na}$ & $M=K$ & $\mathrm{M}=\mathrm{Rb}$ & $\mathrm{M}=\mathrm{Cs}$ \\
\hline 273 & 159 & 492 & 729 & 547 & 476 & 362 \\
\hline 278 & 122 & 349 & 505 & 393 & 345 & 266 \\
\hline 283 & 96.0 & 258 & 364 & 287 & 261 & 200 \\
\hline 288 & 76.6 & 195 & 262 & 214 & 196 & 153 \\
\hline 293 & 62.0 & 150 & 196 & 164 & 151 & 120 \\
\hline 298 & 51.0 & 117 & 149 & 128 & 119 & 97.4 \\
\hline 303 & 42.7 & 92.5 & 119 & 102 & 96.3 & 77.7 \\
\hline 308 & 35.9 & 75.1 & 94.2 & 82.2 & 78.2 & 63.5 \\
\hline 313 & 30.4 & 61.8 & 76.0 & 66.9 & 64.2 & 52.6 \\
\hline 318 & 26.1 & 50.6 & 61.9 & 55.2 & 54.0 & 43.7 \\
\hline 323 & 22.5 & 42.7 & 50.9 & 46.1 & 44.9 & 37.4 \\
\hline 328 & 19.5 & 36.1 & 42.9 & 38.7 & 38.9 & 31.7 \\
\hline 333 & 17.1 & 31.0 & 35.9 & 31.8 & 33.2 & 27.0 \\
\hline 338 & 15.1 & 26.7 & 30.4 & 27.2 & 28.7 & 23.4 \\
\hline 343 & 13.4 & 23.3 & 25.8 & 23.5 & 25.2 & 20.4 \\
\hline 348 & 11.9 & 20.4 & 22.7 & 20.5 & 22.2 & 18.0 \\
\hline 353 & 10.7 & 17.8 & 19.8 & 18.0 & 19.8 & 16.1 \\
\hline 358 & 9.7 & 16.0 & 17.6 & 15.9 & 17.5 & 14.2 \\
\hline 363 & 8.8 & 14.2 & 15.3 & 14.2 & 15.3 & 12.8 \\
\hline 368 & 8.0 & 12.9 & 14.1 & 12.8 & 14.0 & 11.5 \\
\hline 373 & 7.4 & 11.6 & 12.6 & 11.6 & 13.0 & 10.5 \\
\hline 378 & 6.8 & 10.6 & 11.4 & 10.5 & 11.8 & 9.6 \\
\hline 383 & 6.2 & 9.5 & 10.3 & 9.5 & 10.6 & 8.7 \\
\hline 388 & 5.7 & 8.7 & 9.2 & 8.7 & 9.6 & 8.0 \\
\hline
\end{tabular}


Table S2 Ionic conductivities $\left(\mathrm{mS} \mathrm{cm}^{-1}\right)$ of $\left[\mathrm{C}_{4} \mathrm{C}_{1}\right.$ pyrr][FTA] (Pure IL) and M[FTA]$\left[\mathrm{C}_{4} \mathrm{C}_{1}\right.$ pyrr] $][\mathrm{FTA}]$ ionic liquids $(x(\mathrm{M}[\mathrm{FTA}])=0.20 ; \mathrm{M}=\mathrm{Li}, \mathrm{Na}, \mathrm{K}, \mathrm{Rb}, \mathrm{Cs})$.

\begin{tabular}{|c|c|c|c|c|c|c|}
\hline$T / \mathrm{K}$ & Pure IL & $\mathrm{M}=\mathrm{Li}$ & $\mathrm{M}=\mathrm{Na}$ & $M=K$ & $\mathrm{M}=\mathrm{Rb}$ & $\mathrm{M}=\mathrm{Cs}$ \\
\hline 268 & 1.2 & 0.37 & 0.26 & 0.40 & 0.45 & 0.55 \\
\hline 273 & 1.5 & 0.52 & 0.38 & 0.56 & 0.62 & 0.75 \\
\hline 278 & 2.0 & 0.72 & 0.54 & 0.78 & 0.85 & 1.0 \\
\hline 283 & 2.5 & 1.0 & 0.7 & 1.0 & 1.1 & 1.3 \\
\hline 288 & 3.0 & 1.3 & 1.0 & 1.4 & 1.4 & 1.7 \\
\hline 293 & 3.7 & 1.6 & 1.3 & 1.7 & 1.8 & 2.1 \\
\hline 298 & 4.4 & 2.0 & 1.7 & 2.2 & 2.3 & 2.6 \\
\hline 303 & 5.3 & 2.5 & 2.1 & 2.7 & 2.8 & 3.2 \\
\hline 308 & 6.2 & 3.1 & 2.6 & 3.3 & 3.4 & 3.8 \\
\hline 313 & 7.2 & 3.7 & 3.2 & 4.0 & 4.1 & 4.5 \\
\hline 318 & 8.2 & 4.4 & 3.9 & 4.7 & 4.8 & 5.3 \\
\hline 323 & 9.4 & 5.1 & 4.6 & 5.6 & 5.6 & 6.2 \\
\hline 328 & 10.6 & 6.0 & 5.4 & 6.5 & 6.5 & 7.1 \\
\hline 333 & 11.9 & 6.9 & 6.3 & 7.5 & 7.5 & 8.1 \\
\hline 338 & 13.3 & 7.8 & 7.3 & 8.6 & 8.5 & 9.2 \\
\hline 343 & 14.8 & 8.9 & 8.4 & 9.7 & 9.7 & 10.4 \\
\hline 348 & 16.4 & 10.0 & 9.5 & 10.9 & 10.9 & 11.7 \\
\hline 353 & 18.1 & 11.2 & 10.7 & 12.3 & 12.2 & 13.0 \\
\hline 358 & 19.8 & 12.5 & 12.0 & 13.6 & 13.6 & 14.4 \\
\hline 363 & 21.7 & 13.9 & 13.4 & 15.1 & 15.1 & 16.0 \\
\hline 368 & 23.5 & 15.2 & 14.9 & 16.6 & 16.6 & 17.6 \\
\hline 373 & 25.5 & 16.7 & 16.4 & 18.1 & 18.3 & 19.3 \\
\hline 378 & 27.6 & 18.2 & 18.1 & 19.8 & 20.1 & 21.2 \\
\hline 383 & 29.7 & 19.8 & 19.8 & 21.5 & 22.1 & 23.2 \\
\hline 388 & 31.9 & 21.5 & 21.5 & 23.3 & 24.1 & 25.3 \\
\hline
\end{tabular}


Table S3 Densities $\left(\mathrm{g} \mathrm{cm}^{-3}\right)$ and their fitting parameters of $\left[\mathrm{C}_{4} \mathrm{C}_{1}\right.$ pyrr][FTA] (Pure IL) and $\mathrm{M}[\mathrm{FTA}]-\left[\mathrm{C}_{4} \mathrm{C}_{1}\right.$ pyrr $][\mathrm{FTA}]$ ionic liquids $(x(\mathrm{M}[\mathrm{FTA}])=0.20 ; \mathrm{M}=\mathrm{Li}, \mathrm{Na}, \mathrm{K}, \mathrm{Rb}, \mathrm{Cs}){ }^{a}$

\begin{tabular}{|c|c|c|c|c|c|c|}
\hline$T / \mathrm{K}$ & Pure IL & $\mathrm{M}=\mathrm{Li}$ & $\mathrm{M}=\mathrm{Na}$ & $M=K$ & $\mathrm{M}=\mathrm{Rb}$ & $\mathrm{M}=\mathrm{Cs}$ \\
\hline 273 & 1.379 & 1.439 & 1.449 & 1.454 & 1.487 & 1.517 \\
\hline 278 & 1.374 & 1.435 & 1.445 & 1.449 & 1.482 & 1.512 \\
\hline 283 & 1.370 & 1.430 & 1.440 & 1.445 & 1.477 & 1.508 \\
\hline 288 & 1.366 & 1.426 & 1.436 & 1.440 & 1.473 & 1.503 \\
\hline 293 & 1.361 & 1.421 & 1.431 & 1.436 & 1.468 & 1.498 \\
\hline 298 & 1.357 & 1.416 & 1.427 & 1.431 & 1.464 & 1.494 \\
\hline 303 & 1.353 & 1.412 & 1.422 & 1.427 & 1.459 & 1.489 \\
\hline 308 & 1.349 & 1.407 & 1.418 & 1.422 & 1.454 & 1.484 \\
\hline 313 & 1.345 & 1.403 & 1.413 & 1.418 & 1.450 & 1.480 \\
\hline 318 & 1.340 & 1.399 & 1.409 & 1.414 & 1.445 & 1.475 \\
\hline 323 & 1.336 & 1.394 & 1.404 & 1.409 & 1.441 & 1.471 \\
\hline 328 & 1.332 & 1.390 & 1.400 & 1.405 & 1.437 & 1.466 \\
\hline 333 & 1.328 & 1.385 & 1.396 & 1.400 & 1.432 & 1.462 \\
\hline 338 & 1.324 & 1.381 & 1.391 & 1.396 & 1.428 & 1.457 \\
\hline 343 & 1.320 & 1.377 & 1.387 & 1.392 & 1.423 & 1.453 \\
\hline 348 & 1.316 & 1.373 & 1.383 & 1.388 & 1.419 & 1.448 \\
\hline 353 & 1.312 & 1.368 & 1.378 & 1.383 & 1.415 & 1.444 \\
\hline 358 & 1.308 & 1.364 & 1.374 & 1.379 & 1.410 & 1.439 \\
\hline 363 & 1.304 & 1.360 & 1.370 & 1.375 & 1.406 & 1.435 \\
\hline 368 & 1.300 & 1.356 & 1.366 & 1.371 & 1.402 & 1.431 \\
\hline$A_{\rho} \times 10^{4}$ & -8.291 & -8.811 & -8.827 & -8.777 & -8.946 & -9.103 \\
\hline$B_{\rho}$ & 1.605 & 1.679 & 1.690 & 1.693 & 1.730 & 1.765 \\
\hline
\end{tabular}

${ }^{a}$ Density values were fitted by the following equation; $\rho=A_{\rho} T+B_{\rho}$ 
Table S4 Molar concentrations $\left(\mathrm{mol} \mathrm{dm}^{-3}\right)$ and their fitting parameters of alkali metal cations $\left(\mathrm{M}^{+} ; \mathrm{M}=\mathrm{Li}, \mathrm{Na}, \mathrm{K}, \mathrm{Rb}, \mathrm{Cs}\right)$ in $\mathrm{M}[\mathrm{FTA}]-\left[\mathrm{C}_{4} \mathrm{C}_{1}\right.$ pyrr $][\mathrm{FTA}]$ ionic liquids $(x(\mathrm{M}[\mathrm{FTA}])=0.20){ }^{a}$

\begin{tabular}{|c|c|c|c|c|c|}
\hline$T / \mathrm{K}$ & $\mathrm{M}=\mathrm{Li}$ & $\mathrm{M}=\mathrm{Na}$ & $M=K$ & $\mathrm{M}=\mathrm{Rb}$ & $\mathrm{M}=\mathrm{Cs}$ \\
\hline 273 & 0.8336 & 0.8317 & 0.8267 & 0.8235 & 0.8189 \\
\hline 278 & 0.8309 & 0.8290 & 0.8241 & 0.8210 & 0.8163 \\
\hline 283 & 0.8282 & 0.8264 & 0.8215 & 0.8184 & 0.8137 \\
\hline 288 & 0.8256 & 0.8238 & 0.8189 & 0.8158 & 0.8112 \\
\hline 293 & 0.8229 & 0.8212 & 0.8163 & 0.8132 & 0.8086 \\
\hline 298 & 0.8203 & 0.8186 & 0.8138 & 0.8107 & 0.8061 \\
\hline 303 & 0.8177 & 0.8160 & 0.8112 & 0.8082 & 0.8036 \\
\hline 308 & 0.8151 & 0.8134 & 0.8087 & 0.8057 & 0.8011 \\
\hline 313 & 0.8125 & 0.8109 & 0.8062 & 0.8032 & 0.7987 \\
\hline 318 & 0.8099 & 0.8083 & 0.8037 & 0.8007 & 0.7962 \\
\hline 323 & 0.8074 & 0.8058 & 0.8012 & 0.7982 & 0.7937 \\
\hline 328 & 0.8049 & 0.8033 & 0.7987 & 0.7957 & 0.7913 \\
\hline 333 & 0.8023 & 0.8008 & 0.7962 & 0.7933 & 0.7889 \\
\hline 338 & 0.7998 & 0.7983 & 0.7938 & 0.7909 & 0.7864 \\
\hline 343 & 0.7974 & 0.7958 & 0.7913 & 0.7884 & 0.7840 \\
\hline 348 & 0.7949 & 0.7933 & 0.7889 & 0.7860 & 0.7816 \\
\hline 353 & 0.7924 & 0.7909 & 0.7865 & 0.7836 & 0.7793 \\
\hline 358 & 0.7899 & 0.7884 & 0.7840 & 0.7812 & 0.7769 \\
\hline 363 & 0.7875 & 0.7860 & 0.7816 & 0.7788 & 0.7745 \\
\hline 368 & 0.7851 & 0.7836 & 0.7792 & 0.7764 & 0.7722 \\
\hline$A_{C} \times 10^{4}$ & -5.103 & -5.065 & -4.990 & -4.956 & -4.913 \\
\hline$B_{C}$ & 0.9725 & 0.9697 & 0.9626 & 0.9585 & 0.9527 \\
\hline
\end{tabular}

${ }^{a}$ Molar concentration values were fitted by the following equation; $C\left(\mathrm{M}^{+}\right)=A_{C} T+B_{C}$ 
Table S5 Molar ionic conductivities $\left(\mathrm{S} \mathrm{cm}^{2} \mathrm{~mol}^{-1}\right.$ ) of $\left[\mathrm{C}_{4} \mathrm{C}_{1}\right.$ pyrr][FTA] (Pure IL) and M[FTA]$\left[\mathrm{C}_{4} \mathrm{C}_{1}\right.$ pyrr] $[\mathrm{FTA}]$ ionic liquids $(x(\mathrm{M}[\mathrm{FTA}])=0.20 ; \mathrm{M}=\mathrm{Li}, \mathrm{Na}, \mathrm{K}, \mathrm{Rb}, \mathrm{Cs})$.

\begin{tabular}{|c|c|c|c|c|c|c|}
\hline$T / \mathrm{K}$ & Pure IL & $\mathrm{M}=\mathrm{Li}$ & $\mathrm{M}=\mathrm{Na}$ & $\mathrm{M}=\mathrm{K}$ & $\mathrm{M}=\mathrm{Rb}$ & $\mathrm{M}=\mathrm{Cs}$ \\
\hline 273 & 0.41 & 0.12 & 0.091 & 0.14 & 0.15 & 0.18 \\
\hline 278 & 0.53 & 0.17 & 0.13 & 0.19 & 0.21 & 0.25 \\
\hline 283 & 0.67 & 0.23 & 0.18 & 0.25 & 0.27 & 0.32 \\
\hline 288 & 0.83 & 0.31 & 0.24 & 0.33 & 0.36 & 0.41 \\
\hline 293 & 1.01 & 0.39 & 0.32 & 0.43 & 0.45 & 0.52 \\
\hline 298 & 1.22 & 0.50 & 0.41 & 0.54 & 0.57 & 0.65 \\
\hline 303 & 1.45 & 0.62 & 0.52 & 0.67 & 0.70 & 0.79 \\
\hline 308 & 1.70 & 0.75 & 0.65 & 0.82 & 0.85 & 0.95 \\
\hline 313 & 1.98 & 0.91 & 0.80 & 0.99 & 1.02 & 1.13 \\
\hline 318 & 2.29 & 1.08 & 0.96 & 1.18 & 1.20 & 1.33 \\
\hline 323 & 2.62 & 1.27 & 1.15 & 1.39 & 1.41 & 1.55 \\
\hline 328 & 2.97 & 1.48 & 1.35 & 1.63 & 1.64 & 1.80 \\
\hline 333 & 3.35 & 1.71 & 1.58 & 1.88 & 1.89 & 2.06 \\
\hline 338 & 3.75 & 1.96 & 1.83 & 2.16 & 2.16 & 2.34 \\
\hline 343 & 4.19 & 2.23 & 2.10 & 2.46 & 2.46 & 2.65 \\
\hline 348 & 4.64 & 2.52 & 2.40 & 2.78 & 2.77 & 2.98 \\
\hline 353 & 5.13 & 2.83 & 2.71 & 3.12 & 3.11 & 3.34 \\
\hline 358 & 5.64 & 3.16 & 3.05 & 3.48 & 3.48 & 3.72 \\
\hline 363 & 6.19 & 3.52 & 3.42 & 3.86 & 3.87 & 4.12 \\
\hline 368 & 6.74 & 3.87 & 3.80 & 4.27 & 4.28 & 4.55 \\
\hline
\end{tabular}


Table S6 VTF parameters of viscosity and ionic conductivity, and $\alpha$ and $C^{\prime}\left(=\log \left(\lambda \eta^{\alpha}\right)\right)$ parameters for $\left[\mathrm{C}_{4} \mathrm{C}_{1}\right.$ pyrr][FTA] (Pure IL) and $\mathrm{M}[\mathrm{FTA}]-\left[\mathrm{C}_{4} \mathrm{C}_{1}\right.$ pyrr][FTA] ionic liquids $(x(\mathrm{M}[\mathrm{FTA}])=0.20 ; \mathrm{M}=\mathrm{Li}, \mathrm{Na}, \mathrm{K}, \mathrm{Rb}, \mathrm{Cs})$. Concerning the right column, the $\alpha$ and $C^{\prime}$ values correspond to the slopes and vertical intercepts of the Walden plots, and the $B_{\sigma} / B_{\eta}$ values are calculated from the VTF fitting parameters.

\begin{tabular}{|c|c|c|c|c|c|c|c|c|c|}
\hline & \multicolumn{3}{|c|}{ Viscosity } & \multicolumn{3}{|c|}{ Ionic conductivity } & \multicolumn{3}{|c|}{ Walden plot } \\
\hline & $\begin{array}{c}A_{\eta} \times 10^{3} \\
/ \mathrm{mPa} \mathrm{s} \mathrm{K}{ }^{-1 / 2}\end{array}$ & $B_{\eta} / \mathrm{K}$ & $T_{0 \eta} / \mathrm{K}$ & $\begin{array}{c}A_{\sigma} \times 10^{-4} \\
/ \mathrm{mS} \mathrm{cm}^{-1} \mathrm{~K}^{1 / 2}\end{array}$ & $B_{\sigma} / \mathrm{K}$ & $T_{0 \sigma} / \mathrm{K}$ & $\alpha$ & $B_{\sigma} / B_{\eta}$ & $\begin{array}{c}C^{\prime} \\
\left(=\log \left(\lambda \eta^{\alpha}\right)\right)\end{array}$ \\
\hline Pure IL & 4.73 & 1040 & 137 & 2.79 & 958 & 136 & 0.93 & 0.92 & -0.19 \\
\hline $\mathrm{M}=\mathrm{Li}$ & 6.74 & 977 & 157 & 2.08 & 900 & 157 & 0.94 & 0.92 & -0.25 \\
\hline $\mathrm{M}=\mathrm{Na}$ & 5.98 & 1002 & 161 & 2.42 & 916 & 162 & 0.94 & 0.91 & -0.22 \\
\hline $\mathrm{M}=\mathrm{K}$ & 8.56 & 927 & 161 & 1.99 & 852 & 162 & 0.91 & 0.92 & -0.18 \\
\hline $\mathrm{M}=\mathrm{Rb}$ & 6.50 & 1029 & 151 & 2.82 & 973 & 151 & 0.94 & 0.95 & -0.18 \\
\hline $\mathrm{M}=\mathrm{Cs}$ & 4.73 & 1086 & 144 & 3.12 & 1013 & 144 & 0.93 & 0.93 & -0.21 \\
\hline
\end{tabular}


Table S7 Summary of the redox potentials of $\mathrm{M}^{+} / \mathrm{M}\left(E\left(\mathrm{M}^{+} / \mathrm{M}\right) ; \mathrm{M}=\mathrm{Li}, \mathrm{Na}, \mathrm{K}, \mathrm{Rb}, \mathrm{Cs}\right)$ in various electrolytes at $298 \mathrm{~K}$.

\begin{tabular}{|c|c|c|c|c|c|c|}
\hline \multirow{2}{*}{ Electrolyte } & \multicolumn{5}{|c|}{$E\left(\mathrm{M}^{+} / \mathrm{M}\right) / \mathrm{V}$ vs. $\mathrm{Ag}^{+} / \mathrm{Ag}$} & \multirow{2}{*}{ Ref. } \\
\hline & $E\left(\mathrm{Li}^{+} / \mathrm{Li}\right)$ & $E\left(\mathrm{Na}^{+} / \mathrm{Na}\right)$ & $E\left(\mathrm{~K}^{+} / \mathrm{K}\right)$ & $E\left(\mathrm{Rb}^{+} / \mathrm{Rb}\right)$ & $E\left(\mathrm{Cs}^{+} / \mathrm{Cs}\right)$ & \\
\hline $\begin{array}{c}\mathrm{M}[\mathrm{FTA}]- \\
{\left[\mathrm{C}_{4} \mathrm{C}_{1} \text { pyrr }\right][\mathrm{FTA}]^{*}}\end{array}$ & -3.48 & -3.36 & -3.67 & -3.71 & -3.83 & $\begin{array}{l}\text { This } \\
\text { study }\end{array}$ \\
\hline $\begin{array}{c}\mathrm{M}[\mathrm{FSA}]- \\
{\left[\mathrm{C}_{3} \mathrm{C}_{1} \text { pyrr }\right][\mathrm{FSA}]^{* *}}\end{array}$ & -3.46 & -3.35 & -3.71 & $\mathrm{n} / \mathrm{a}$ & $\mathrm{n} / \mathrm{a}$ & $\mathrm{a}$ \\
\hline $1 \mathrm{~mol} \mathrm{dm}^{-3} \mathrm{M}^{+} / \mathrm{PC}$ & -3.78 & -3.55 & -3.87 & -3.94 & -4.09 & $\mathrm{~b}$ \\
\hline $1 \mathrm{~mol} \mathrm{dm}^{-3} \mathrm{M}^{+} / \mathrm{MeCN}$ & -3.29 & -3.12 & -3.44 & -3.44 & -3.53 & $\mathrm{~b}$ \\
\hline $1 \mathrm{~mol} \mathrm{dm}^{-3} \mathrm{M}^{+} /$Water & -3.839 & -3.513 & -3.735 & -3.742 & -3.826 & $\mathrm{~b}$ \\
\hline $1 \mathrm{~mol} \mathrm{dm}^{-3} \mathrm{M}^{+} / \mathrm{EtOH}$ & -3.78 & -3.42 & -3.62 & -3.63 & -3.72 & $\mathrm{~b}$ \\
\hline $1 \mathrm{~mol} \mathrm{dm}^{-3} \mathrm{M}^{+} / \mathrm{DMF}$ & -3.72 & -3.39 & -3.62 & -3.62 & -3.72 & $\mathrm{~b}$ \\
\hline $1 \mathrm{~mol} \mathrm{dm}^{-3} \mathrm{M}^{+} / \mathrm{NMP}$ & -3.93 & -3.40 & -3.58 & -3.56 & -3.66 & $\mathrm{~b}$ \\
\hline $1 \mathrm{~mol} \mathrm{dm}^{-3} \mathrm{M}^{+} / \mathrm{DMSO}$ & -3.64 & -3.29 & -3.51 & -3.49 & -3.60 & $\mathrm{~b}$ \\
\hline
\end{tabular}

$\mathrm{PC}=$ propylene carbonate, $\mathrm{MeCN}=$ acetonitrile, $\mathrm{EtOH}=$ ethanol, $\mathrm{DMF}=N, N$-dimethylformamide, $\mathrm{NMP}=$ $\mathrm{N}$-methylpyrrolidone, DMSO = dimethyl sulfoxide

* Values of M[FTA $]-\left[\mathrm{C}_{4} \mathrm{C}_{1}\right.$ pyrr] $[\mathrm{FTA}]$ were measured at the molar concentration of M[FTA] of $0.820 \mathrm{~mol}$ $\mathrm{dm}^{-3}$ for Li[FTA], $0.819 \mathrm{~mol} \mathrm{dm}^{-3}$ for Na[FTA], $0.814 \mathrm{~mol} \mathrm{dm}^{-3}$ for K[FTA], $0.811 \mathrm{~mol} \mathrm{dm}^{-3}$ for Rb[FTA], $0.806 \mathrm{~mol} \mathrm{dm}^{-3}$ for Cs[FTA].

** Values of M[FSA]-[C $\mathrm{C}_{3} \mathrm{C}_{1}$ pyrr] $[\mathrm{FSA}]$ were measured at the molar concentration of M[FSA] of $1.0 \mathrm{~mol}$ $\mathrm{dm}^{-3}$ for Li[FSA], ${ }^{\mathrm{c}} 0.98 \mathrm{~mol} \mathrm{dm}^{-3}$ for $\mathrm{Na}[\mathrm{FSA}],{ }^{\mathrm{d}}$ and $0.98 \mathrm{~mol} \mathrm{dm}^{-3}$ for K[FSA]. ${ }^{\mathrm{a}}$

(a) Yamamoto, T.; Matsumoto, K.; Hagiwara, R.; Nohira, T. Physicochemical and Electrochemical Properties of $\mathrm{K}\left[\mathrm{N}\left(\mathrm{SO}_{2} \mathrm{~F}\right)_{2}\right]-\left[\mathrm{N}-\right.$ Methyl-N-propylpyrrolidinium] $\left[\mathrm{N}\left(\mathrm{SO}_{2} \mathrm{~F}\right)_{2}\right]$ Ionic Liquids for Potassium-Ion Batteries. J. Phys. Chem. C 2017, 121, 18450-18458.

(b) Marcus, Y. Thermodynamic Functions of Transfer of Single Ions from Water to Nonaqueous and Mixed Solvents, PART 3: Standard Potentials of Selected Electrodes. Pure Appl. Chem. 1985, 57, 1129-1132.

(c) Yoon, H.; Best, A. S.; Forsyth, M.; MacFarlane, D. R.; Howlett, P. C. Physical properties of high Liion content $N$-propyl- $N$-methylpyrrolidinium bis(fluorosulfonyl)imide based ionic liquid electrolytes. Phys. Chem. Chem. Phys. 2015, 17, 4656-4663.

(d) Matsumoto, K.; Okamoto, Y.; Nohira, T.; Hagiwara, R. Thermal and Transport Properties of $\mathrm{Na}\left[\mathrm{N}\left(\mathrm{SO}_{2} \mathrm{~F}\right)_{2}\right]-[N$-Methyl- $N$-propylpyrrolidinium $]\left[\mathrm{N}\left(\mathrm{SO}_{2} \mathrm{~F}\right)_{2}\right]$ Ionic Liquids for $\mathrm{Na}$ Secondary Batteries. J. Phys. Chem. C 2015, 119, 7648-7655. 


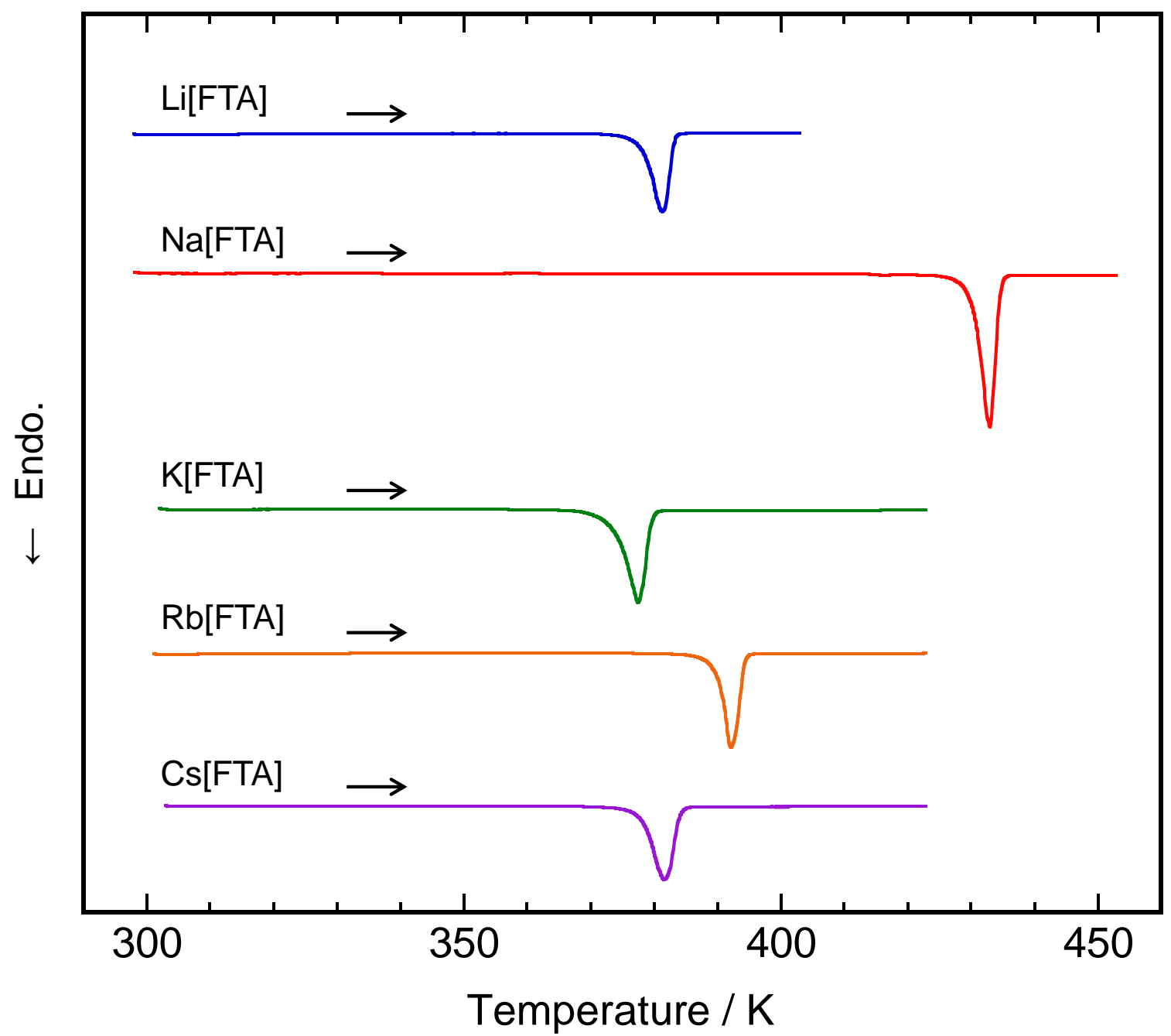

Fig. S1 DSC curves of M[FTA] salts (M = Li, Na, K, Rb, Cs). Scan rate: $2 \mathrm{~K} \mathrm{~min}^{-1}$.

The onset and end temperatures of melting are found to be 378 and $383 \mathrm{~K}$ for Li[FTA], 430 and $435 \mathrm{~K}$ for $\mathrm{Na}$ [FTA], 373 and $380 \mathrm{~K}$ for K[FTA], 390 and $395 \mathrm{~K}$ for Rb[FTA], and 378 and $384 \mathrm{~K}$ for Cs[FTA], respectively. These results are almost consistent with the previous report. ${ }^{\mathrm{e}}$ The small deviations might be attributed to the difference of the measurement conditions.

(e) Kubota, K.; Nohira, T.; Hagiwara, R.; Matsumoto, H. Thermal Properties of Alkali (Fluorosulfonyl)(trifluoromethylsulfonyl)amides. Chem. Lett. 2010, 39, 1303-1304. 